\title{
CYPERACEAE DO PARQUE ESTADUAL PAULO CÉSAR VINHA, GUARAPARI, ESPÍRITO SANTO, BRASIL
}

\author{
Márcio Lacerda Lopes Martins ${ }^{1}$ \\ Rita Maria de Carvalho-Okano ${ }^{2}$ \\ Modesto Luceño ${ }^{3}$
}

Recebido em 25/08/1998. Aceito em 10/07/1999

\begin{abstract}
RESUMO - (Cyperaceae do Parque Estadual Paulo César Vinha, Guarapari, Espírito Santo, Brasil). Este trabalho consiste no levantamento dos representantes de Cyperaceae da restinga do Parque Estadual Paulo César Vinha, Guarapari, Brasil. A família está representada no local por 38 espécies. São apresentadas descrições, ilustrações, chaves de identificação e comentários para todos os táxons.
\end{abstract}

Palavras-chave - Cyperaceae, flora, restinga, Espírito Santo, Brasil

ABSTRACT - (Çyperaceae of the Paulo César Vinha State Park, Guarapari, Espírito Santo, Brazil). In this paper are presented 38 species of Cyperaceae, ocorring in the "restinga" vegetation of the Paulo César Vinha State Park, Guarapari, Brazil. Descriptions, illustrations, comments and keys to identification are presented.

Key words - Cyperaceae, flora, restinga, Espírito Santo, Brazil

\section{Introdução}

O Parque Estadual Paulo César Vinha (PEPCV) localiza-se no litoral sul do Espírito Santo, município de Guarapari (20³3'-20³8'S e $\left.40^{\circ} 23^{\prime}-40^{\circ} 26^{\prime} \mathrm{W}\right)$ e possui área de $1.480 \mathrm{ha}$, com comprimento de aproximadamente $12 \mathrm{~km}$ e largura média de $2 \mathrm{~km}$. É constituído basicamente por planície arenosa com vegetação característica, comumente chamada "restinga". Fitofisionomicamente, Pereira (1990a) distingue 11 formações vegetais na restinga do PEPCV (Fig. 1): Halófila, Psamófila-reptante, Pós-praia, Palmae, Mata de Myrtaceae, Mata Seca, Mata Perio- dicamente Inundada, Mata Permanentemente Inundada, Brejo Herbáceo, Formação Aberta de Clusia e Formação Aberta de Ericaceae. O Parque apresenta ainda duas lagoas, uma laguna e um pequeno campo de dunas.

Estudos sobre a taxonomia de Cyperaceae, no PERCV são inexistentes, tendo alguns de seus gêneros simplesmente citados em listagens florísticas (Pereira 1990b; Pereira \& Gomes 1993).

Taxonomicamente, estudos sobre a família no Brasil estão restritos aos de Nees (1842), englobando todo o território, Barros (1960), no Estado de Santa Catarina, e Luceño et al. (1997),

\footnotetext{
Bolsista da CAPES (Demanda Social). Curso de Pós-graduação em Botânica

Departamento de Biologia Vegetal, Universidade Federal de Viçosa, CEP 36571-000, Viçosa, MG, Brasil

${ }^{3}$ Real Jardim Botânico de Madrid, Plaza de Murillo, 228014 Madrid, Espanha
} 


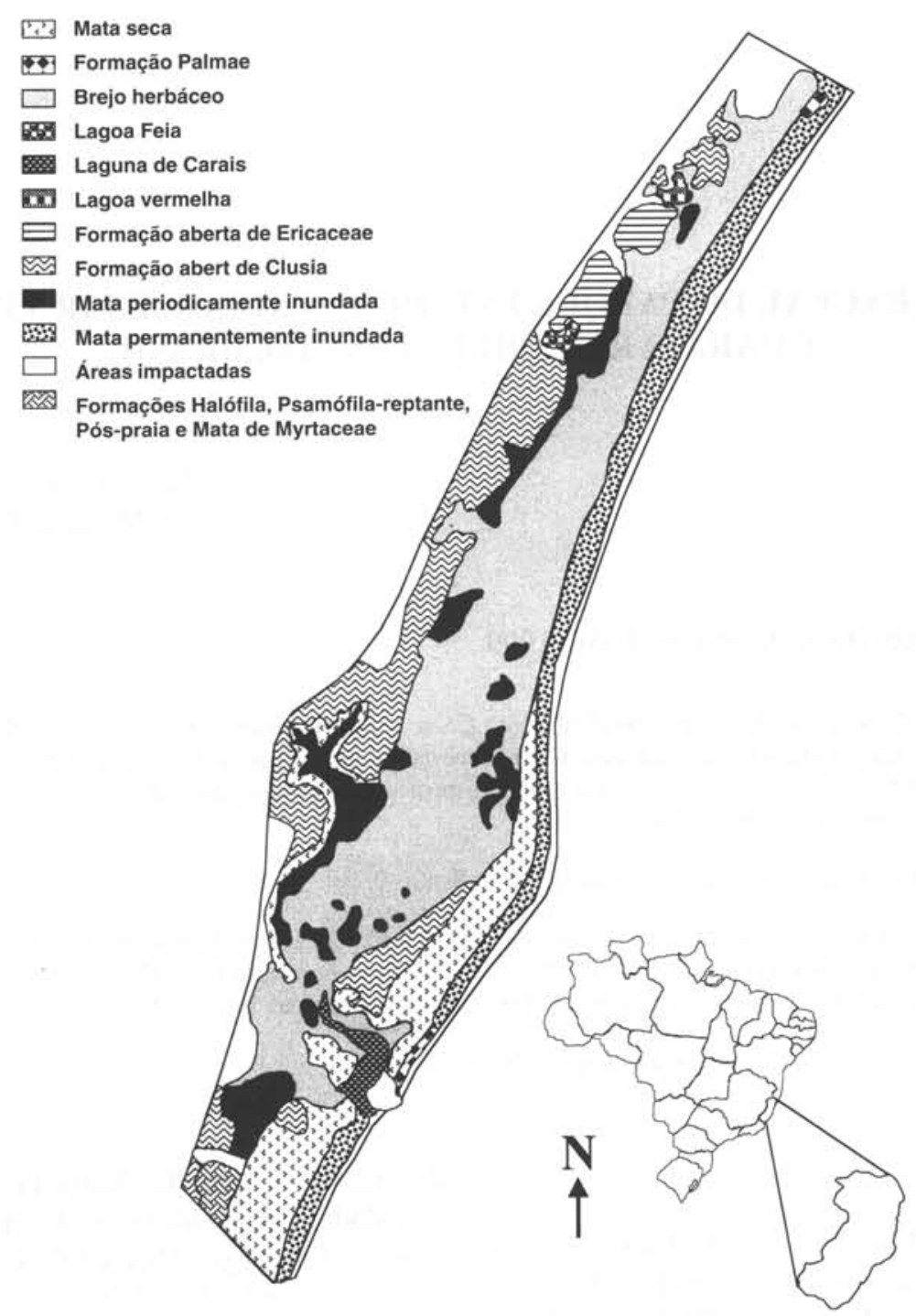

Figura 1. Localização do Parque Estadual Paulo César Vinha, Guarapari, Espírito Santo e distribuição das formações vegetais segundo Pereira (1990a) (Fonte SEDESU 1996).

nos Estados de Pernambuco e Paraíba. Luceño \& Alves (1997) apresentam chave para a identificação dos gêneros brasileiros da família. Entretanto, estudos taxonômicos ainda são escassos, restringindo-se a descrições de novos táxons e a levantamentos de floras regionais.

O presente trabalho teve por objetivo realizar o levantamento das Cyperaceae ocorrentes no PERCV, elaborar descrições, ilustrações, chaves de identificação para gêneros e espécies e fornecer comentários sobre os táxons.

\section{Material e métodos}

Foram realizadas visitas mensais ao PEPCV no período de 16 meses consecutivos, a partir de setembro/1995, para coleta de material botânico. Durante as coletas foram percorridas trilhas préexistentes e realizadas caminhadas sem orientação pré-estabelecida em todas as formações vegetais. $\mathrm{O}$ material coletado foi identificado e depositado nos herbários da Universidade Federal de Viçosa (VIC), da Universidade Federal do Espírito Santo 
(VIES), e da Universidade Federal de Pernambuco (UFP).

As descrições foram baseadas no material botânico coletado na área do PEPCV, sendo mencionadas as dimensões mínima e máxima, e colocadas entre parênteses as variações extremas. Comentários sobre a morfologia, distribuição e habitat das espécies são apresentados após cada descrição.

\section{Resultados e discussão}

Chave para os gêneros de Cyperaceae

1. Espiguetas com flores díclinas

2. Aquênios esféricos 13. Scleria

2. Aquênios oblongos

3. Perianto composto por duas peças membranáceas

7. Hypolytrum

3. Perianto ausente ..........9. Lagenocarpus

1. Espiguetas com flores monóclinas ou monóclinas e díclinas masculinas

4. Glumas dísticas ou subdísticas

5. Base do estilete dilatada 1. Abildgaardia

5. Base do estilete não dilatada

6. Aquênio trígono, estigmas-3

7. Folhas não rosuladas, lanceoladas, aquênios não recobertos

3. Cyperus

7. Folhas rosuladas, pontiagudas, aquênios recobertos por uma gluma esponjosa, rizomas caracteristicamente alongados .... 11. Remirea

6. Aquênio biconvexo, estigmas-2

8. Espiguetas unifloras, com duas glumas, inflorescência globosa......

8. Kyllinga

8. Espiguetas plurifloras, com mais de duas glumas dispostas disticamente, inflorescência de outra forma, aquênio com o bordo adjacente ao eixo da espigueta 10. Pycreus

4. Glumas helicoidais

9. Estilopódio persistente

10.Folhas reduzidas às bainhas

4. Eleocharis

10.Folhas com lâminas
11.Aquênio lenticular, estigmas 1 ou 2 , espiguetas geralmente paucifloras .

12. Rhynchospora

11.Aquênio trígono, estigmas geralmente 3 , espiguetas multifloras .....

2. Bulbostylis

9. Estilopódio caduco ou ausente

12.Estilopódio caduco

5. Fimbristylis

12.Estilopódio ausente

6. Fuirena

1. Abildgaardia Vahl, Enum. Pl. 2: 296. 1806.

Ervas perenes, cespitosas. Rizomas geralmente curtos. Caules filiformes, pendentes, geralmente cobertos por bainhas foliares velhas na base. Folhas mais curtas que o caule, basais, lineares ou filiformes, espiraladas, aplanadas, levemente escabrosas, glabras, algumas vezes sem lâmina; bainha com margem hialina, frágil; lígula e contralígula ausentes. Inflorescências com 1-3 espiguetas terminais, ovadas; glumas subdísticas, quilhadas, curto-mucronadas, decíduas; flores monóclinas ou raramente díclinas; perianto ausente; estames 2-3; estigmas 3, estilete trígono, indiviso, geralmente piloso, estilopódio caduco. Aquênios trígonos, obovóides a subglobosos, com superfície geralmente verrucosa.

\subsection{Abildgaardia scirpoides Nees, Linnaea} 9: 289.1835.

Fig. 2-5

Perenes, cespitosas. Rizomas 1-2x0,15$0,20 \mathrm{~cm}$. Caules $(8) 12-18(23) \times 0,5-0,8 \mathrm{~cm}$, filiformes, pendentes, glabros. Folhas reduzidas a bainhas; bainhas cobrindo até 1/7 do comprimento dos caules, glabras, pardo-alaranjadas, com ápice longamente oblíquo e acuminado. Inflorescências terminais com 1-3 espiguetas; espiguetas (5)8$11(14) \times 2-5 \mathrm{~mm}$, oblongo-lanceoadas a oblongoelípticas, achatadas ou torcidas; glumas 3-4×2$3 \mathrm{~mm}$, dísticas a subdísticas, triangulares, quilhadas, curto-mucronadas, glabras, pardas, bordos transparentes com manchas avermelhadas e três nervuras centrais mais nítidas, decíduas; flores monóclinas, estames 3; estigmas 3, estilete piloso na porção superior, estilopódio trígono, 

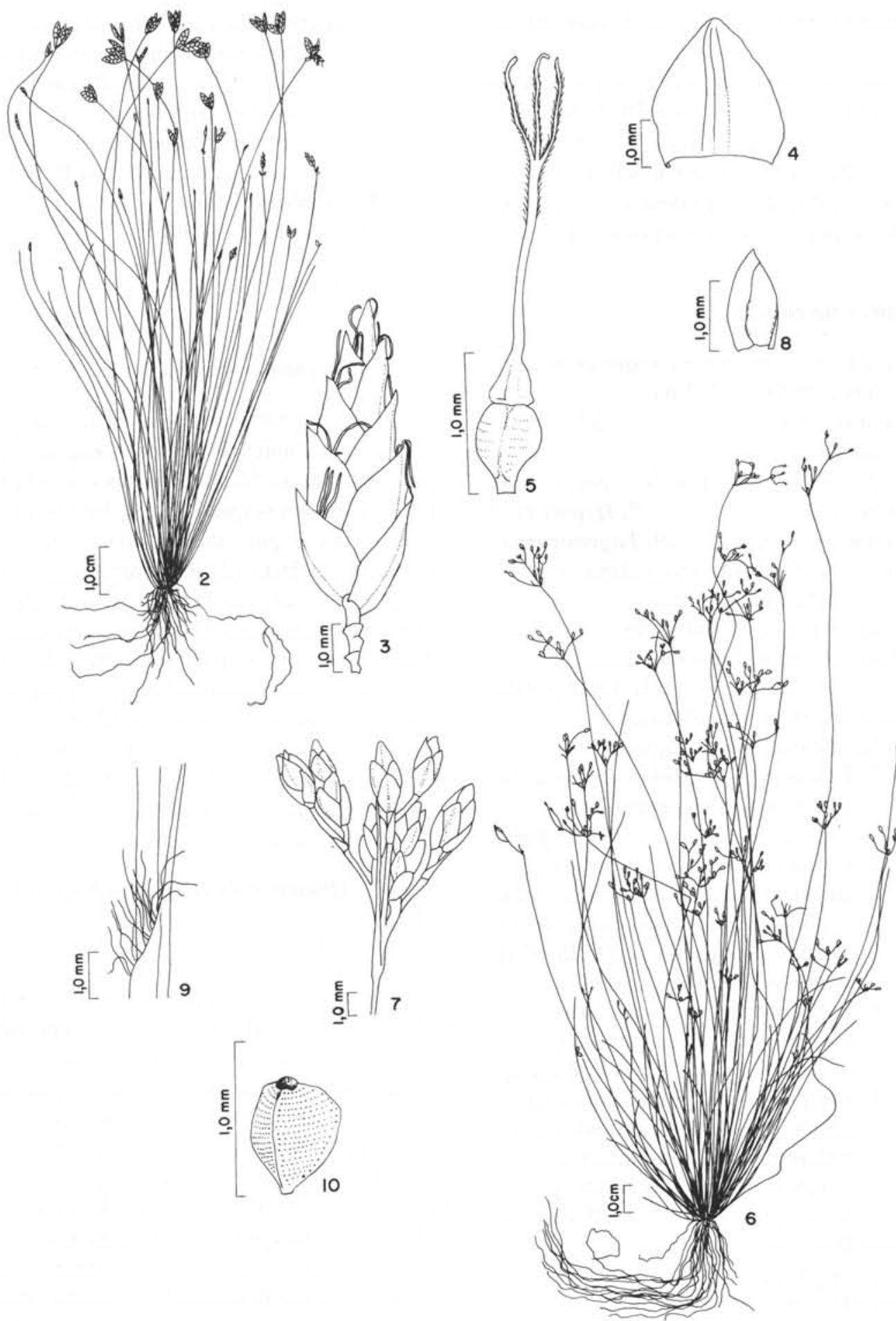

Figuras 2-10. Abildgaardia scirpoides Nees. 2. Aspecto geral; 3. Espiqueta; 4. Gluma; 5. Gineceu (Martins 713). Bulbostylis capillaris (L.) Clarke. 6. Aspecto geral; 7. Detalhe da inflorescência; 8. Gluma; 9. Porção distal da bainha; 10. aquênio (Martins 758). 
piramidal, caduco. Aquênios $(0,3) 0,6-0,9 \times 0,25-$ $0,6 \mathrm{~mm}$, trígonos, obpiramidais, brancos, superfície rugosa.

Material examinado: BRASIL. Espírito Santo: Formação Aberta de Ericaceae, VIII/1987 (fl., fr.), Pereira 970, (VIES); Formação Aberta de Clusia, I/1996 (fl., fr.), Martins 699 (VIC, UFP); Formação Palmae, I/1996 (fl., fr.), Martins 712 (VIC, UFP); Formação Mata Seca, V/1996 (fl., fr.), Martins 736 (VIC); Formação Aberta de Ericaceae, VI/1996 (fl., fr.), Martins 760 (VIC).

A. scirpoides caracteriza-se por apresentar espiguetas terminais, geralmente em número de 2 ou 3, glumas pardas a levemente manchadas de vermelho, de disposição dística a subdística. Os representantes de $A$. scirpoides ocorrentes nas formações abertas de Clusia e Ericaceae, apresentam porte de ca. $15-18 \mathrm{~cm}$, enquanto que na formação Mata Seca estes são mais robustos chegando, às vezes, aos $25 \mathrm{~cm}$. Provavelmente, essa variação seja devido à diferença de umidade do solo destas formações. É citada para Pernambuco e Paraíba por Luceño et al. (1997).

\section{Bulbostylis Kunth, Enum. Pl. 2: 205. 1837.}

Ervas anuais ou perenes de vida curta, cespitosas. Rizomas geralmente curtos. Caules filiformes, pendentes. Folhas mais curtas que o caule, basais, capilares ou filiformes, espiraladas, aplanadas ou canaliculadas, algumas vezes levemente escabrosas, glabras; bainha algumas vezes com bordos fimbriados; lígula e contralígula ausentes. Inflorescências terminais com espiguetas ovadas ou elípticas reunidas em pseudo-umbelas, glomérulos ou fascículos; glumas helicoidais ou raramente subdísticas, decíduas, as inferiores estéreis; flores monóclinas, perianto ausente; estames 1-3; estigmas 3, estilete achatado ou trígono, indiviso, glabro, estilopódio persistente. Aquênios trígonos, obovóides, obtusos ou truncados, superfície rugosa, papilosa ou reticulada.

Chave para as espécies de Bulbostylis

1. Espiguetas sésseis ou subsésseis, bainhas aladas 2. B. junciformis

1. Espiguetas pediceladas, bainhas não aladas
2. Aquênios lisos 3. B. scabra

2. Aquênios rugosos 1. B. capillaris

2.1. Bulbostylis capillaris (L.) C. B. Clarke in Hook f., Fl. Brit. Ind. 6: 652. 1893.

Scirpus capillaris L., Sp. Pl.: 49.1753.

Fig. 6-10

Anuais, cespitosas. Rizomas curtos. Caules $17-24(33) \times 0,02-0,05 \mathrm{~cm}$, filiformes, irregularmente quadrangulares, sulcados, pendentes, glabros. Folhas $(1,6) 2,5-6,5(8,5) \times 0,01-0,03 \mathrm{~cm}$, basais, filiformes, ligeiramente canaliculadas, escabrosas nos bordos, glabras; bainhas glabras, pardo-claras, bordos oblíquos, extremidades fimbriadas, claros, pouco densos. Inflorescências terminais, umbeliformes, raios até $2 \mathrm{~cm}$; espiguetas (1) 2-5(8)x 1-2mm, oblongo-lanceoladas, 3-6 por caule, sendo uma séssil; glumas 1,2-1,8xca. $1 \mathrm{~mm}$, helicoidais, ovado-orbiculares, quilhadas, pilosas nas margens, rubro-pardas, decíduas; estames 3; estigmas 3, estilete glabro, estilopódio negro, obscuramente piramidal. Aquênios $0,6-0,9 \times 0,5-$ $0,7 \mathrm{~mm}$, trígonos, obpiramidais, de coloração parda à cinza, superfície levemente estriada.

Material examinado: BRASIL. Espírito Santo: Formação Aberta de Clusia, XI/1985 (fl., fr.), Pereira 419 (VIES); Formação Aberta de Ericaceae, VI/1996 (fl., fr.), Martins 758 (VIC); Formação Palmae, VIII/1996 (fl., fr.), Martins s/ $n^{o}$ (VIC),

B. capillaris caracteriza-se por apresentar aquênios com superfície rugosa e glumas pilosas em toda a superfície externa, além de inflorescências mais abertas e porte menor que $B$. scabra. B. capillaris ocorre nas formações abertas de Clusia e de Ericaceae, na região de entre-moitas, e em áreas abertas da formação Palmae, indicando preferência por ambientes expostos ao sol e com baixa umidade, como constatado por Kral (1971) e Adams citado por Davidse et al. (1994). Há registros de $B$. capillaris para o Rio de Janeiro (Araújo \& Henriques 1984), Espírito Santo (Pereira 1990a), Santa Catarina (Barros 1960), Paraíba e Pernambuco (Luceño et al. 1997); Kral (1971) cita-a para a flora dos Estados Unidos, sendo raro registros na América do Sul e Sudeste da Ásia. 
2.2. Bulbostylis junciformis (H. B. K.) C. B. Clarke ex S. Moore, Trans. Linn. Soc. Ser. II. 4: 512.1895.

Isolepis junciformis $\mathrm{H}$. B. K., Nov. Gen. et Sp. 1: 222. 1816.

Fig. 11-15

Perenes, cespitosas. Rizomas 10-20x0,5$1 \mathrm{~mm}$. Caules (23)25-35(50) x0,05-0,10cm, trígonos, filiformes, sulcados, pendentes, levemente escabrosos, glabros. Folhas geralmente não ultrapassando a metade do comprimento do caule, basais, filiformes, levemente canaliculadas, com bordos antrorsamente escabrosos, glabras; bainhas aladas, pardas e fimbriadas. Inflorescências terminais em glomérulos ou subumbeliformes, raios 1-4, suportando glomérulos terminais e um central séssil; espiguetas $2-4 \times 1 \mathrm{~mm}$, ovallanceoladas, sésseis; glumas 1,8-2,8 $\times 1,5 \mathrm{~mm}$, helicoidais, oval-lanceoladas, levemente mucronadas, glabras, pardo-rubras, decíduas; nervura central verde, pilosa; estames 2-3; estigmas 3, estilete glabro, estilopódio pouco desenvolvido, globoso e escuro. Aquênios 0,6-0,8x0,3-0,5mm, trígonos, obpiramidais, branco-acinzentados, superfície tenuemente reticulada ou ponteada.

Material examinado: BRASIL. Espírito Santo: Formação Aberta de Ericaceae, V/1987 (fl., fr.), Pereira 901 \& Fabris 116 (VIES); Formação Aberta de Ericaceae, V/1996 (fl., fr.), Martins 733 (VIC, UFP); Formação Aberta de Clusia, VIII/1996 (fl., fr.), Martins 784 (VIC).

B. junciformis caracteriza-se por apresentar espiguetas sésseis, aquênio caracteristicamente ponteado e bainhas aladas. B. junciformis ocorre nas formações abertas de Clusia e Ericaceae, na região de entre-moitas, assim como B. capillaris. Adams citado por Davidse et al. (1994) caracteriza seu habitat como savanas arenosas e bosques abertos, e Kral (1971) considera freqüente sua ocorrência em associação com B. tenuifolia Nees, o que não foi verificado no PEPCV. Distribui-se na América, do México ao Rio de Janeiro (Uittien 1966).

2.3. Bulbostylis scabra (J. \& C. Presl) Lindm., Bih. Svensk. Vet. \& Akad. Handl. 26, n 9, 18.1898.
Isolepis scabra J. \& C. Presl, Rel. Haenk. 188. 1828.

Fig. 16-20

Anuais, cespitosas. Caules 7-17x0,1-0,5cm, filiformes, sulcados, geralmente pendentes, glabros. Folhas 15-30(50)x0,1-0,3mm, basais, filiformes, canaliculadas, antrorsamente escabrosas nos bordos, glabras; bainhas pardo-claras, com extremidade oblíqua e fimbriada. Inflorescências terminais, umbeli-formes, raios com até $1 \mathrm{~cm}$ comp.; brácteas 2 , eretas, a maior excedendo as espiguetas; espiguetas $1-3 \mathrm{xca}$. $1 \mathrm{~mm}, 3-6$ por caule, ovadas à oblongas, sendo uma séssil; glumas ca. $1 \times 0,5-0,7 \mathrm{~mm}$, helicoidais, ovadas à obovadas, quilhadas, diminutamente ciliadas nas margens e na superfície externa, rubro-pardas, nervura central verde, decíduas; estames 2-3; estigmas 3 , estilopódio negro. Aquênios 0,5$0,8 \times 0,5-0,7 \mathrm{~mm}$, trígonos, obpiramidais, pardos à branco-perolados, superfície lisa.

Material examinado: BRASIL. Espírito Santo: Formação Aberta de Ericaceae, VI/1996 (fl., fr.), Martins 761 (VIC); Formação Aberta de Clusia, I/1996 (fl., fr.), Martins 698 (VIC).

B. scabra caracteriza-se por apresentar aquênios com superfície lisa e glumas pilosas na superfície externa, caracteres que a distinguem de B. capillaris. B. scabra foi encontrada apenas nas formações abertas de Clusia e Ericaceae. No Brasil, há registros para Santa Catarina, Rio Grande do Sul, Rio Grande do Norte e Pernambuco (Barros 1960).

\section{Cyperus L., Syst. ed. I. 1753.}

Ervas anuais ou perenes, cespitosas. Rizomas com comprimento variável. Caules geralmente trígonos, eretos ou pendentes, escabrosos ou não, glabros. Folhas com comprimento e forma variáveis, algumas vezes sem lâmina, freqüentemente basais, comumente escabrosas e glabras; lígula e contralígula ausentes. Inflorescências terminais em glomérulos ou panículas umbeliformes; espiguetas geralmente comprimidas, com eixo persistente ou caduco, com brácteas foliáceas; glumas dísticas a subdísticas, as duas inferiores estéreis; flores monóclinas, perianto ausente, 


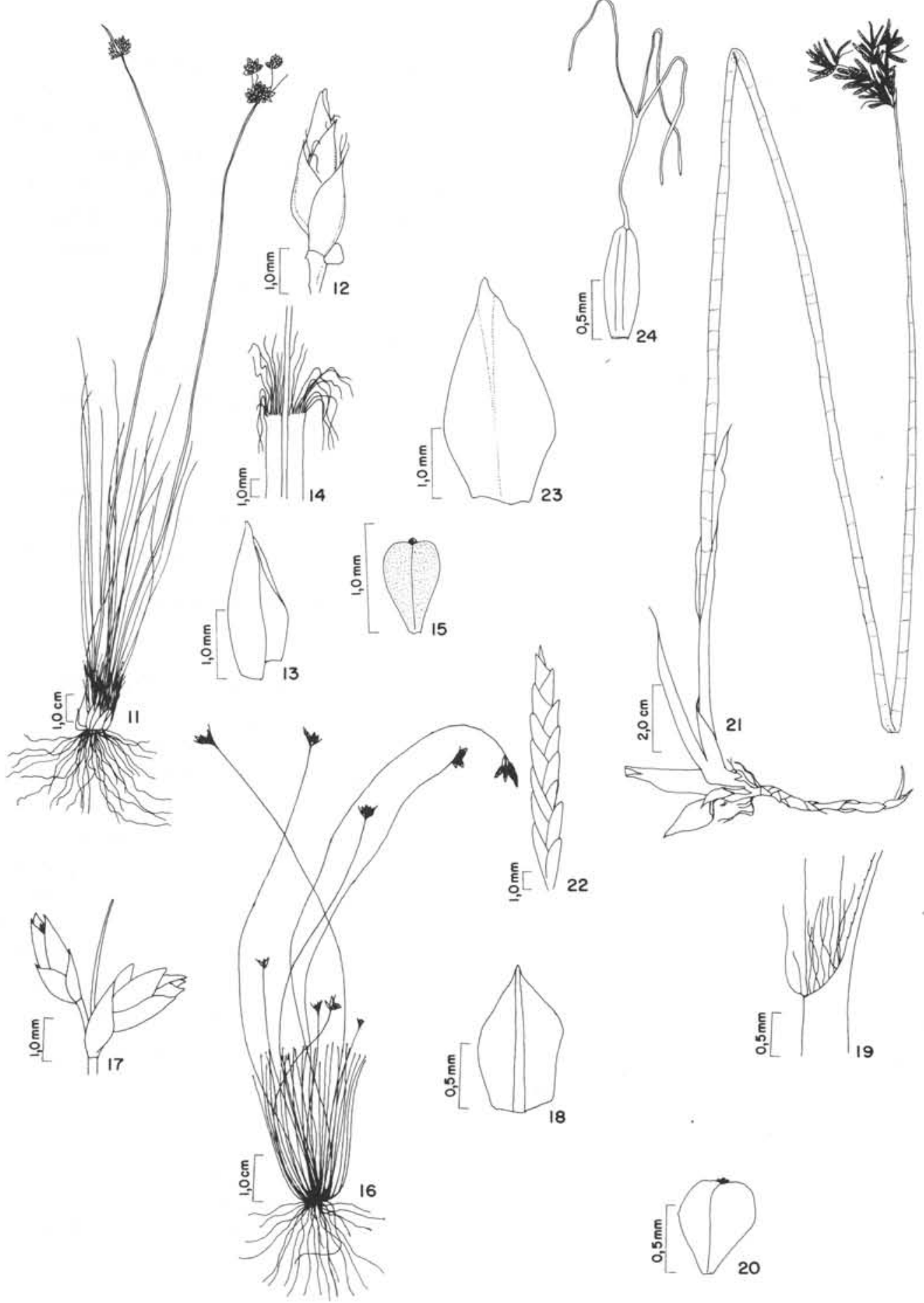

Figuras 11-24. Bulbostylis junciformis (H. B. K.) C. B. Clarke ex S. Moore. 11. Aspecto geral; 12. Espigueta; 13. Gluma; 14. Porção distal da bainha; 15. Aquênio (Martins 733). Bulbostylis scabra (J. \& C. Presl) Lindm. 16. Aspecto geral; 17. Detalhe da inflorescência; 18. Gluma; 19. Porção distal da bainha; 20. Aquênio (Martins 761). Cyperus articulatus L. 21. Aspecto geral; 22 . Espigueta; 23. Gluma; 24. Aquênio (Martins 746). 
estames 1-3, estigmas 1-3, estilete glabro, estilopódio ausente. Aquênios trígonos ou, raramente, dorsiventralmente comprimidos, obovados ou subglobosos, com superfície lisa ou ponteada.

Chave para as espécies de Cyperus

1. Caule cilíndrico, claramente septado.

1. C. articulatus

1. Caule trígono, não septado

2. Glumas caducas, eixo da espigueta persistente

3. Caule escabroso .......2. C. surinamensis

3. Caule não-escabroso ......... 4. C. haspan

2. Glumas persistentes, espiguetas caducas

4. Espiguetas bastante densas ocultando a raque, glumas pardas à purpúreas, caules e folhas glaucos devido à grande quantidade de papilas

3. C. ligularis

4. Espiguetas laxas exibindo a raque, glumas esverdeadas, caules e folhas verdes, sem papilas

5. C. tenuis

3.1. Cyperus articulatus L., Sp. Pl.: 44. 1753. Fig. 21-24

Perenes, cespitosas. Rizomas 3-6x0,3-0,5cm, coberto por escamas foliáceas, rosadas. Caules $60-$ $100(110) \times 0,2-0,5 \mathrm{~cm}$, cilíndricos, eretos, glabros, claramente septados; septos $1,5-3 \mathrm{~cm}$. Folhas reduzidas a bainhas; bainhas $1-3$, com ca. de $1 / 5$ do comprimento do caule, glabras, com extremidade oblíqua de coloração parda, porém vinosa na base. Inflorescências terminais, subumbeliformes, raios 5-10, até $5 \mathrm{~cm}$ compr.; espiguetas (6) 15-20(26) x1-2mm, oblongo-lanceoladas, achatadas, fasciculadas, sésseis; glumas $3 \times 1$ $1,3 \mathrm{~mm}$, dísticas, ovado-elípticas, glabras, purpúreas, com bordos membranáceos translúcidos; nervura central, levemente esverdeada; estames 3 ; estigmas 3 , estilete glabro. Aquênios 1-1,3x0,3$0,4 \mathrm{~mm}$, obviamente trígonos, oblongos, apiculados, pardos, superfície ponteada.

Material examinado: BRASIL. Espírito

Santo: Laguna de Caraís, I/1996 (fl., fr.), Martins 672 (VIC, UFP); I/1996 (fl., fr.), Martins 705 (VIC).

C. articulatus é caracterizada pelo caule cilíndrico e septado com até $2 \mathrm{~m}$ de comprimento e folhas sem lâmina. Os septos tornam-se mais aparentes em plantas herborizadas, como citado por Koyama (1979). Adams (Davidse et al. 1994) propôs para esta espécie duas variedades, $C$. articulatus var. articulatus e $C$. articulatus var. nodosus, baseado no porte e na presença ou não da lâmina foliar. Segundo o autor, $C$. articulatus var. articulatus não possui lâmina foliar e alcança acima de $100 \mathrm{~cm}$ de altura, enquanto que $C$. articulatus var. nodosus mede ca. $70 \mathrm{~cm}$ e apresenta lâmina foliar. Como estas características variam de acordo com o habitat desta espécie, preferiu-se desconsiderar estas variedades. $C$. articulatus ocorre somente no bordo da laguna de Caraís. A ocorrência em ambientes de água salobra também foi constatada por vários autores (Scholz \& Scholz 1983; Berghen 1988; Adams citado por Davidse et al. (1994). No Brasil é citada para Pernambuco e Paraíba (Luceño et al. 1997).

3.2. Cyperus haspan L., Sp. Pl.: 45. 1753. Fig. 25-28

Perenes, cespitosas. Rizomas curtos, ca. $0,5 \mathrm{~cm}$ diâm. Caules $35-70 \times 0,18-0,35 \mathrm{~cm}$, triquetros, eretos ou pendentes, glabros. Folhas reduzidas a bainhas; bainhas alcançando até 1/3 do comprimento do caule, glabras, purpúreoescuras, com extremidade oblíqua. Inflorescências terminais, subumbeliformes; raios primários 10 15 , com no máximo $3 \mathrm{~cm}$; raios secundários 2-5, $0,1-0,35 \mathrm{~mm}$; raios terciários raros, curtíssimos; brácteas 2, (9)27-38(45) mm de comprimento, secção transversal em "V", a bráctea inferior maior e ereta; espiguetas 3-7xca. $1 \mathrm{~mm}$, oval-lanceoladas, fasciculadas, achatadas; glumas $1-1,5 \times 0,8-1 \mathrm{~mm}$, dísticas, ovadas, quilhadas, mucronadas, glabras, pardo-purpúreas; nervura central verde, decíduas; estames 3; estigmas 3, estilete glabro. Aquênios 0,3-0,6 $\times 0,15-0,25 \mathrm{~mm}$, trígonos, obovados, pardoclaros, superfície levemente granulosa.

Material examinado: BRASIL. Espírito Santo: Formação Brejo Herbáceo, VI/1996 (fl., fr.), Martins 757 (VIC, UFP).

C. haspan caracteriza-se pelo caule geralmente triquetro, aquênios albos a albo-pardos e pela ausência de lâmina foliar, embora Tucker (1994) admita a presença de lâmina foliar em 


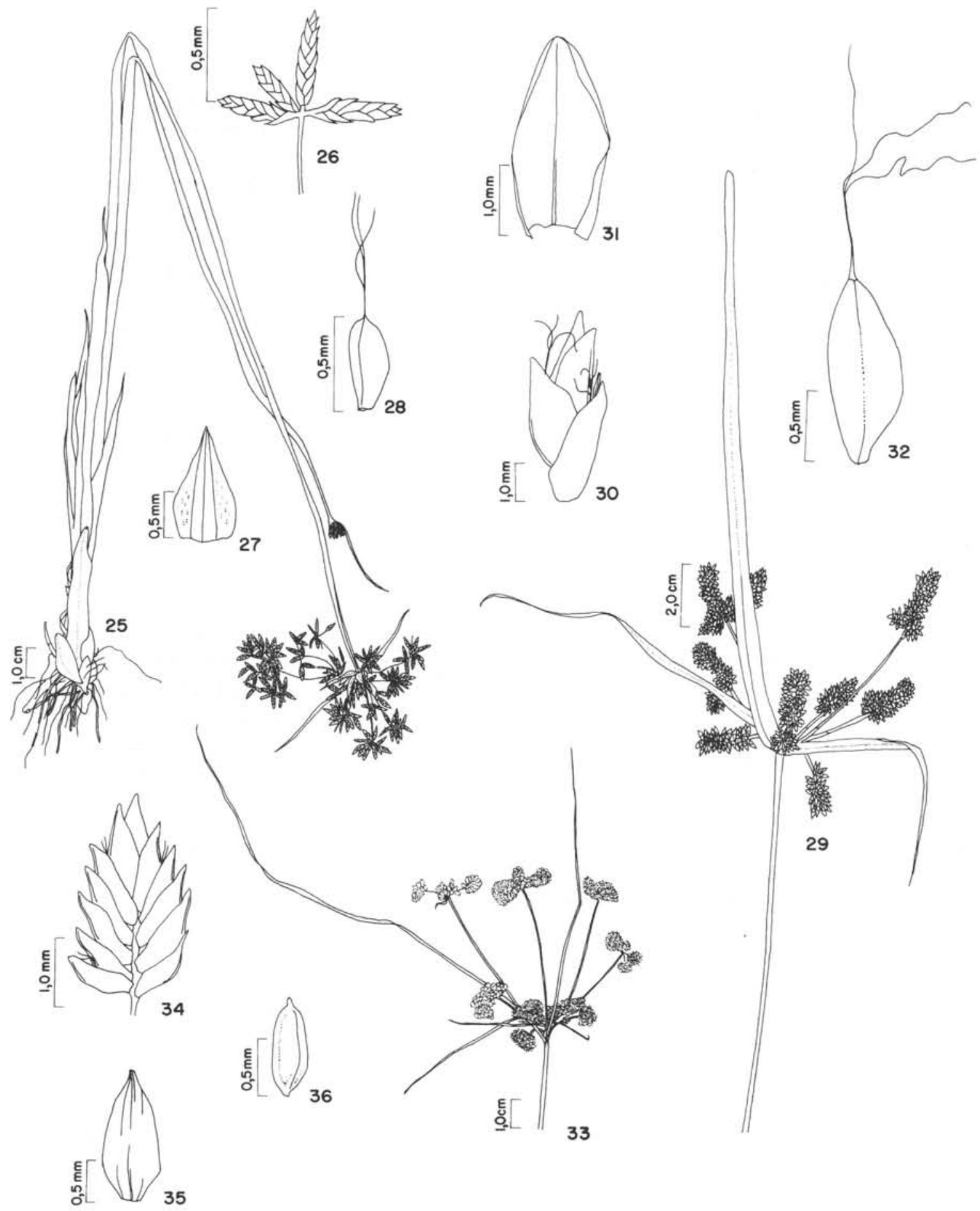

Figuras 25-36. Cyperus haspan L. 25. Aspecto geral; 26. Detalhe da inflorescência; 27. Gluma; 28. Aquênio ( Martins 747). Cyperus ligularis L. 29. Aspecto geral; 30. Espigueta; 31. Gluma; 32. Aquênio (Martins 745). Cyperus surinamensis Rottb. 33. Aspecto geral; 34. Espigueta; 35. Gluma; 36. Aquênio (Martins 746). 
alguns indivíduos. De acordo com o autor, essa espécie apresenta porte bastante variável, medindo de 2 a $100 \mathrm{~cm}$; entretanto, esta variação não foi verificada nos representantes do PEPCV, talvez pelo fato desta espécie ocorrer apenas em uma única comunidade. Grande variação também pode ser verificada no formato do aquênio, de orbicular a ovóide ou subovóide, no comprimento dos raios da inflorescência, e no comprimento da lâmina foliar, freqüentemente presente, mas em nosso material ausente. C. haspan é referido, por Adams citado por Davidse et al. (1994), como ocorrente em pântanos, bordos de lagos e poças d'água, no entanto, Tucker (1994) relata para as espécies mexicanas ocorrência rara em solos úmidos ou lamacentos, sendo encontrada mais frequientemente em solos perturbados. No PEPCV, $C$. haspan ocorre somente na formação Brejo Herbáceo; há registros para São Paulo (Muniz 1987), Santa Catarina, Rio de Janeiro, Bahia, Goiás e Minas Gerais (Nees 1842), Pernambuco e Paraíba (Luceño et al. 1997).

3.3. Cyperus ligularis L., Syst. Nat. ed. 10, 867. 1759.

Fig. 29-32

Perenes cespitosas. Rizomas $2-10 \times 1-2 \mathrm{~cm}$. Caules (60)70-100(140)x0,3-0,6cm, trígonos a cilíndricos, papilosos, eretos, glabros, verdeglaucos. Folhas de comprimento geralmente superior ao do caule, 0,4-1 cm larg., basais, lanceoladas, bordos e nervura central escabrosos, glabras, septadas; bainha recobrindo até $1 / 5$ do comprimento do caule, com extremidade truncada. Inflorescências terminais com 7-11 raios eretos a patentes, papilosos, glabros, cada um acompanhado por uma bráctea; bráctea $(17,5) 25$ $40(57) \times(0,15) 0,30-0,90 \mathrm{~cm}$, foliácea, com as mesmas características das folhas; espigas 3-8, 1$35 \times 7-12 \mathrm{~mm}$, oblongas, a terminal séssil, as demais dispostas perpendicularmente ao raio, suspensas por raios secundários de no máximo $1 \mathrm{~cm}$; espiguetas 3-5,5x1-1,5mm, densamente agrupadas ao redor do raio, oval-lanceoladas, paucifloras, decíduas; glumas 2,1-3x1-1,8mm, dísticas, ovalelípticas, glabras, pardo-rosadas, com bordos membranáceos; estames 3 ; estigmas 3 , estilete glabro. Aquênios 1,2-1,5x0,3-0,7 mm, trígonos, obovóides a oblongos, apiculados, pardos, superfície ponteada.

Material examinado: BRASIL. Espírito Santo: Afloramento rochoso próximo à Laguna de Caraís, III/1991 (fl., fr.), Gomes 1494 (VIES); Formação Palmae, V/1996 (fl., fr.), Martins 743 (VIC); Formação Aberta de Clusia, V/1996 (fl., fr.), Martins 745 (VIC).

C. ligularis é facilmente distinta das demais espécies de Cyperus por possuir espiguetas reunidas distalmente nos raios e densamente agrupadas, além de apresentar caules e folhas freqüientemente papilosos e glaucos. C. ligularis está distribuída nas formações Pós-praia, Palmae, na região de entre-moitas da formação aberta de Clusia e em áreas degradadas. Na formação Palmae, essa espécie só foi encontrada na porção sul do parque, onde a vegetação está mais exposta à ação dos ventos e recebe freqüentemente borrifos de água do mar, uma vez que na porção norte a formação Palmae está protegida pelas dunas. $\mathrm{Na}$ formação aberta de Clusia aparece em áreas já alteradas pela extração de areia, atividade freqüente antes da criação do parque. Tucker (1994) e Adams citado por Davidse et al. (1994) referem-se a C. ligularis como comum em praias arenosas, pântanos salobros, mangues e solos degradados.

\subsection{Cyperus surinamensis Rottb., Desc. Pl.} Rar.: 20. 1772.

Fig. 33-36

Perenes ou anuais, cespitosas. Rizomas ca. 3-4 mm diâm. Caules com até $70 \times 0,25 \mathrm{~cm}$, trígonos, eretos, retrorsamente escabrosos, glabros. Folhas com comprimento pouco menor que o caule, 2-4mm larg., basais, lineares, secção transversal em "V", bordos e nervura central escabrosos, glabros; bainha membranácea, purpúrea. Inflorescências terminais, raios primários (14)25-60x0,5-1,0mm, algumas vezes bastante reduzidos, achatados, retrorsamente escabrosos, glabros; brácteas de até $27 \times 1,5-3 \mathrm{~mm}$, foliáceas, antrorsamente escabrosas nos bordos; espiguetas 3-4x1,5-2 mm, oval-oblongas, achatadas; glumas 1,3-1,5x0,8-1 mm, dísticas, ovadas, 
quilhadas, levemente mucronadas, glabras, trinérveas, verde-amareladas; nervura central verde, bordos membranáceos; estame 1; estigmas 3 , estilete glabro. Aquênios 0,7-0,8x0,2-0,4mm, trígonos, oval-oblongos, apiculados, superfície ponteada.

Material examinado: BRASIL. Espírito Santo: Bordo da trilha dos guardas que corta a formação Brejo Herbáceo, V/1996 (fl., fr.), Martins 746 (VIC); bordo da trilha central do parque, VIII/1996 (fl., fr.), Martins 797 (VIC); Formação não determinada, XI/1988 (fl., fr.), Gomes 528 (VIES); Formação não determinada, XI/1988 (fl., fr.), Gomes 529 (VIES); Formação não determinada, III/1989 (fl., fr.), Gomes 540 (VIES).

C. surinamensis é facilmente reconhecida por apresentar os ângulos e faces do caule e os raios da inflorescência retrorsamente escabrosos. Distribui-se nas áreas degradadas, em trilhas de solo argiloso que anteriormente eram utilizadas para a passagem de veículos. Tucker (1994) cita C. surinamensis como comum em áreas degradadas expostas à intensa radiação solar. Adams citado por Davidse et al. (1994) a relaciona a locais ensolarados, sombreados lodosos ou terrenos arenosos com água doce e salobra.

3.5. Cyperus tenuis Sw., Prodr.: 20. 1788. Fig. $37-40$

Perenes, cespitosas. Rizomas 3-10xca. 0,2cm. Caules (10)20-35(50)x0,1-0,2cm, trígonos, eretos, glabros. Folhas com metade do comprimento do caule, com 2-3mm larg., basais, lineares, com bordos e nervura central antrorsamente escabrosos, glabras, secção transversal em "V", com base vinosa. Inflorescências terminais, raios 3-7, 2-6cm compr., cada um acompanhado de uma bráctea; brácteas $3-15 \times 0,15-0,25 \mathrm{~cm}$, foliáceas, com bordos e nervura central antrorsamente escabrosos, glabras; espiguetas 5-9xca. $1 \mathrm{~mm}$, no terço distal dos raios ou sésseis, perpendicularmente dispostas em relação ao raio, lineares a oblongas, paucifloras, decíduas; glumas 2,8-3,2x1,2-1,6mm, dísticas, oblongo-elípticas, levemente mucronadas, glabras, pardas, nervura central esverdeada; estames 3; estigmas 3, estilete glabro. Aquênios 1,7-2x0,4-0,6mm, trígonos, oblongo-elípticos, levemente recurvados, apiculados, pardos, superfície ponteada.

Material examinado: BRASIL. Espírito Santo: Mata de Myrtaceae, I/1996 (fl., fr.), Martins 717 (VIC, UFP); Formação Aberta de Clusia, XII/1996 (fl., fr.), Martins 809 (VIC).

C. tenuis é caracterizada por possuir espiguetas decíduas cilíndricas, glumas esverdeadas, lineares, curtamente mucronadas e aquênios oblongos a lineares. C. tenuis ocorre em locais ensolarados, geralmente nos bordos das trilhas da Mata de Myrtaceae e na região de entre-moitas da Formação Aberta de Clusia. Adams citado por Davidse et al. (1994) refere-se a C. tenuis como invasora de culturas e áreas perturbadas. Tucker (1994) comenta que no México esta espécie é invasora de plantações de banana e café, além de ocorrer em bordos de estradas. Distribui-se nas Américas, do México ao Brasil, e na África tropical (Tucker 1994).

\section{Eleocharis R. Br., Prodr.: 224. 1810.}

Ervas perenes ou anuais, aquáticas ou de solos úmidos. Rizomas geralmente curtos. Caules cilíndricos, angulosos ou triquetros, eretos ou pendentes. Folhas reduzidas a bainhas na base do caule, geralmente glabras. Inflorescências reduzidas a uma espigueta solitária terminal, geralmente cilíndrica, glumas helicoidais, raramente subdísticas, glabras, decíduas, as inferiores estéreis; flores monóclinas, perianto (0)3-9 cerdas com pelos retrorsos; estames 1-3; estigmas 2-3, estilete glabro, estilopódio persistente. Aquênios trígonos ou lenticulares, com superfície lisa ou reticulada.

Chave para as espécies de Eleocharis

1. Caule com diâmetro maior que $2 \mathrm{~mm}$

2. Caule trígono 5. E. mutata

2. Caule cilíndrico 2. E. interstincta

1. Caule com diâmetro menor que $1,5 \mathrm{~mm}$

3. Cerdas hipogínicas mais curtas que o aquênio 3. E. maculosa

3. Cerdas hipogínicas mais longas que o aquênio 4. Aquênio pardo a esverdeado 4. E. minima 4. Aquênio negro ............. 1. E. geniculata 


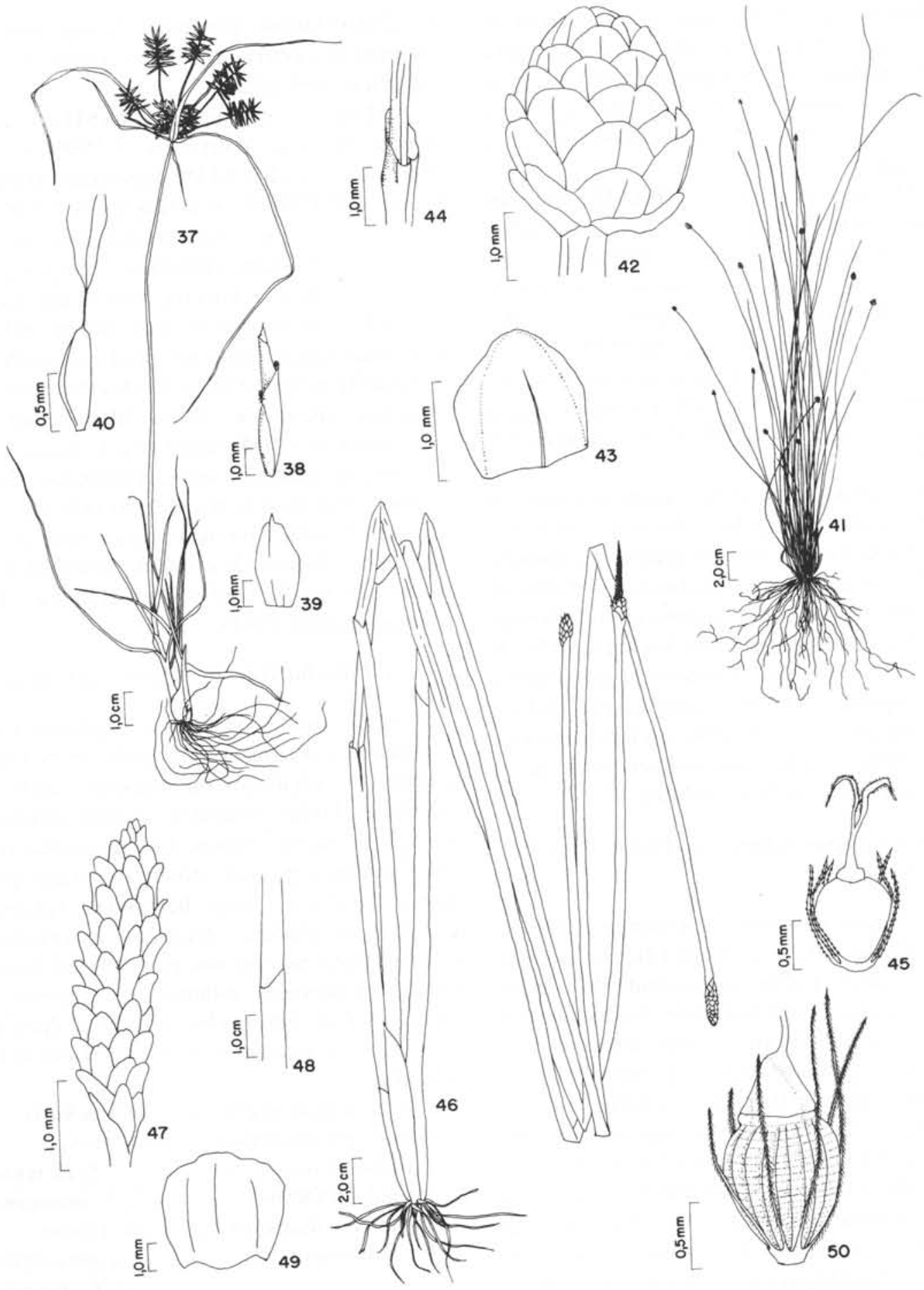

Figuras 37-50. Cyperus tenuis Sw. 37. Aspecto geral; 38. Espigueta; 39. Gluma; 40. Aquênio ( Martins 717). Eleohcaris geniculata (L.) Roem. \& Schult. 41. Aspecto geral; 42. Espigueta; 43. Gluma; 44. Porção distal da bainha; 45. Aquênio (Martins 637). Eleocharis interstincta (Vahl) Roem. \& Schult. 46. Aspecto geral; 47. Espigueta; 48. Porção distal da bainha; 49. Gluma; 50. Aquênio (Martins 747). 
4.1. Eleocharis geniculata (L.) Roem. \& Schult., Syst. Veg. 2: 150 .1817.

Scirpus geniculatus L., Sp. Pl.: 48. 1753. Fig. 41-45

Anuais, cespitosas. Caules $(1,7) 10$ $20(40) \times 0,04-0,10 \mathrm{~cm}$, achatados, sulcados, eretos, glabros. Folhas reduzidas a bainhas; bainhas $(0,4) 1$ $4(6) \mathrm{cm}$, glabras, com extremidade resistente, oblíqua e aguda, parda no ápice e púrpurea na base. Espiguetas 1,5-3,0(4,0)x(1,2)1,5-2,5mm, ovóides a globosas; glumas 1,3-2x1,2-1,5mm, helicoidais, obovadas, com ápice obtuso, membranáceas, pardas, às vezes com manchas púrpuras, decíduas; perianto com 6-8 cerdas, pouco maiores que o aquênio, ou ainda 2-3 menores que as demais, retrorsamente escabrosas, pardas; estames 2-3; estigmas 2, estilete glabro, estilopódio deprimido. Aquênios 0,8-1,1x0,5-0,8mm, biconvexos, obovados, negros, superfície lisa e brilhante.

Material examinado: BRASIL. Espírito Santo: Formação Breje Herbáceo, IX/1995 (fl., fr.), Martins 627 (VIC, UFP); Formação Pós-praia, III/1996 (fl., fr.), Martins 720 (VIC, UFP); Formação Brejo Herbáceo, V/1996 (fl., fr.), Martins 730 (VIC, UFP); Formação Pós-praia, VIII/1996 (fl., fr.), Martins 789 (VIC); Formação Pós-praia, VIII/1996 (fl., fr.), Martins 790 (VIC).

E. geniculata é caracterizada por possuir espiguetas ovóides a suborbiculares, ápice da bainha resistente, oblíquo e purpúreo, e aquênio negro e liso. Esta espécie apresenta porte bastante variável, de 1,7 a $40 \mathrm{~cm}$, provavelmente, esta variação esteja relacionada à ocupação de ambientes tão distintos, como as formações Brejo Herbáceo e Pós-praia. A abundância de E. geniculata no brejo é notável, à semelhança de E. mutata e E. interstincta. Berghen (1988) inclui entre os locais de ocorrência desta espécie terrenos salinos e depressões em dunas litorâneas iniciais, características da formação Póspraia.

4.2. Eleocharis interstincta (Vahl) Roem. \& Schult., Syst. Veg. 2: 149. 1817.

Scirpus interstinctus Vahl, Enum. P1. 2: 251. 1805. Fig. 46-50
Perenes, cespitosas. Rizomas curtos. Caules até $120 \times 0,4-0,8 \mathrm{~cm}$, cilíndricos, septados, eretos, glabros. Bainhas com até $1 / 6$ do comprimento do caule, glabras, pardas a pardo-vinosas, de ápice oblíquo. Espiguetas 2-4x0,4-0,8cm, cilíndricas; glumas ca. $4 \times 3-4 \mathrm{~mm}$, helicoidais, obovadas a orbiculares, cartilaginosas, glabras, com margens geralmente ciliadas, pardo-claras ou levemente esverdeadas, decíduas; perianto com 6(-8) cerdas, retrorsamente escabrosas; estames 3 ; estigmas 23 , estilete glabro, estilopódio cônico. Aquênios 2,5-3xca. $2 \mathrm{~mm}$, lenticulares, pardo-amarelados, superfície reticulada.

Material examinado: BRASIL. Espírito Santo: Lagoa Vermelha, I/1996 (fl., fr.), Martins 747 (VIC, UFP); Formação Brejo Herbáceo, I/ 1996 (fl., fr.), Martins 751 (VIC).

E. interstincta caracteriza-se por possuir cerdas hipogínicas mais longas que o aquênio, e caule cilíndrico, o que a diferencia facilmente de E. mutata, já que nesta ele é trígono. E. interstincta ocorre apenas na formação Brejo Herbáceo e na Lagoa Vermelha. De acordo com González citado por Davidse et al. (1994), E. interstincta é típica de matas ou savanas alagadas. No Brasil ocorre no Pará (Svenson 1929), Santa Catarina, Paraná e Rio de Janeiro (Barros 1960).

4.3. Eleocharis maculosa (Vahl) Roem. \& Schult., Syst. Veg. 2: 154. 1817. 1805.

Scirpus maculosus Vahl, Enum. Pl. 2: 247.

\section{Fig. 51-55}

Perenes, cespitosas. Rizomas 5-6x0,1-0,2cm. Caules $28-35 \times 0,05-0,10 \mathrm{~cm}$, sulcados, eretos ou pendentes, glabros, verde-amarelados. Bainhas 2,5-5cm, ápice oblíquo, membranáceo, pardo, base purpúrea. Espiguetas 5-10x1,2-3,5mm, ovallanceoladas, escuras; glumas (2)2,5-3(3,2) x1,2$1,5 \mathrm{~mm}$, helicoidais, oval-lanceoladas, membranáceas, glabras, purpúreas a negras, com bordos transparentes, decíduas; perianto com 6-8 cerdas mais curtas que o aquênio, retrorsamente escabrosas; estames 3; estigmas 2, estilete glabro, estilopódio piramidal. Aquênios 0,8-1,2 x0,5$0,7 \mathrm{~mm}$, oval-elípticos, pardo-escuros a negros, superfície lisa. 


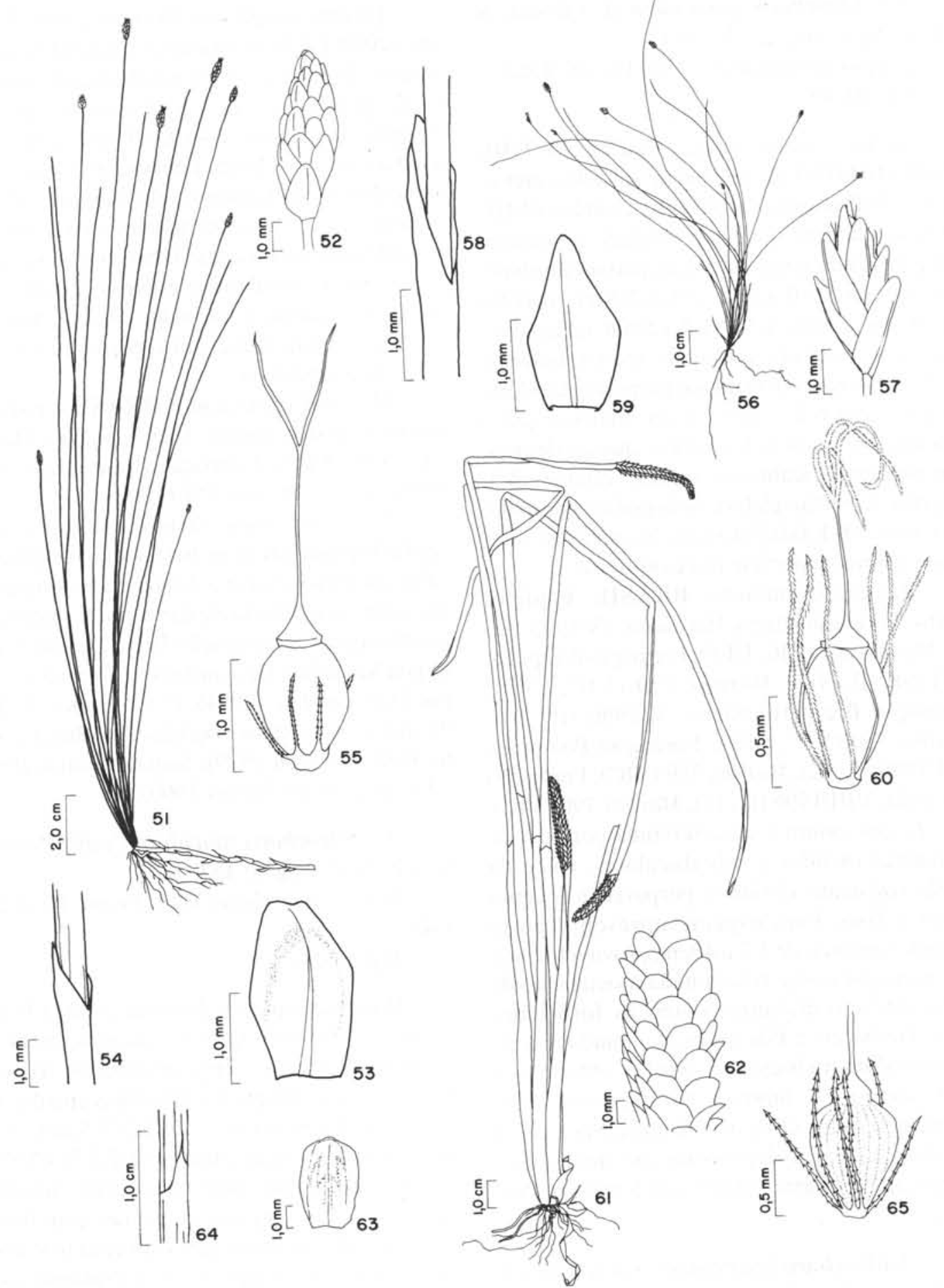

Figuras 51-65. Eleocharis maculosa (Vahl) Roem. \& Schult. 51. Aspecto geral; 52. Espigueta; 53. Gluma; 54. Porção distal da bainha: 55. Aquênio (Martins 680). Eleohcaris minima Kunth. 56. Aspecto geral; 57. Espigueta; 58. Porção distal da bainha. 59. ( Eleocharis mutata (L.) Roem. \& Schult. 61. Aspecto geral; 62. Espigueta; 63. Gluma; 64. Porção distal da bainha; 65 . Aquênio (Martins 670). 
Material examinado: BRASIL. Espírito Santo: Formação Brejo Herbáceo, I/1996 (fl., fr.), Martins 680 (VIC, UFP); Formação Brejo Herbáceo, I/1996 (fl., fr.), Martins 690 (VIC, UFP).

E. maculosa caracteriza-se pelas espiguetas ovóides a elípticas, glumas purpúreo-escuras, o que confere a espigueta coloração enegrecida, bainhas com extremidades esbranquiçadas, e aquênios negros. $\mathrm{O}$ aquênio apresenta a superfície lisa, embora Uittien (1966) faça referência a aquênios de superfície levemente reticulada. As cerdas hipogínicas são sempre mais curtas que o aquênio em nosso material, conforme citado por Koyama (1979), no entanto, diversos autores fazem menção a cerdas tão ou mais longas que o aquênio (Svenson 1929; Uittien 1966). No PEPCV, E. maculosa foi encontrada apenas na formação Brejo Herbáceo. Segundo González citado por Davidse et al. (1994), esta espécie habita áreas úmidas em bosques de Pinus e bosques montanhosos, portanto, sua ocorrência na formação Brejo Herbáceo parece incomum. É referida para o Paraná, São Paulo, Rio de Janeiro, Bahia (Svenson 1929), Santa Catarina (Barros 1960), Paraíba e Pernambuco (Luceño et al. 1997).

4.4. Eleocharis minima Kunth, Enum. Pl. 2: 139.1837.

Fig. 56-60

Anuais, cespitosas. Caules 5,5-10(25)x0,01$0,02 \mathrm{~cm}$, filiformes, sulcados, eretos ou pendentes, glabros. Bainhas 1,6-4cm, pardo-rosadas, ápice oblíquo, membranáceo. Espiguetas oval-lanceoladas; glumas ca. 2 xca. $1 \mathrm{~mm}$, helicoidais, glabras, pardas, algumas vezes maculadas, nervura central verde, decíduas; perianto com 5-7 cerdas brancas, retrorsamente escabrosas, geralmente mais longas que o aquênio; estames 2-3; estigmas 2-3, estilete glabro, estilopódio piramidal, esverdeados. Aquênios 0,6-0,8 $\times 0,4-0,6 \mathrm{~mm}$, trígonos, com ângulos definidos, obovados a globosos, brancopardos, superfície ponteada, levemente reticulada ou lisa.

Material examinado: BRASIL. Espírito Santo: Formação Brejo Herbáceo, IX/1995 (fl., fr.), Martins 621 (VIC); Formação Brejo Her- báceo, IX/1995 (fl., fr.), Martins 624 (VIC, UFP); Formação Brejo Herbáceo, IX/1995 (fl., fr.), Martins 625 (VIC, UFP); Formação Brejo Herbáceo, I/1996 (fl., fr.), Martins 706 (VIC, UFP); Formação Brejo Herbáceo, III/1996 (fl., fr.), Martins 719 (VIC, UFP).

E. minima caracteriza-se pelos caules capilares que comumente ficam pendentes, espiguetas geralmente curtas e paucifloras, freqüentemente vivíparas, com 6-10 flores, e ápice da bainha membranáceo (Barros 1960; González citado por Davidse et al. 1994). E. minima ocorre apenas na formação Brejo Herbáceo. Distribui-se por Minas Gerais, Mato Grosso, São Paulo, Rio Grande do Sul (Svenson 1937), Santa Catarina (Barros 1960), Paraíba e Pernambuco (Luceño et al. 1997).

4.5. Eleocharis mutata (L.) Roem. \& Schult., Syst. Veg. 2: 155. 1817.

Scirpus mutatus L., Syst. ed. X. 867. 1759.

Fig. 61-65

Perenes, cespitosas. Rizomas curtos. Caules 30-80 $0,3-0,4 \mathrm{~cm}$, triquetros, eretos, glabros. Bainhas com até $1 / 3$ do comprimento do caule, membranáceas, pardo-purpúreas, extremidade oblíqua, aguda e glabra. Espiguetas 25-40x4-5mm, cilíndricas; glumas $4 \times 3-4 \mathrm{~mm}$, helicoidais, orbiculares a obovadas, subcartilaginosas, com bordos membranáceos, levemente carenadas, pardas, algumas vezes maculadas, ápice obtuso; perianto com 6 cerdas, retrorsamente escabrosas; estames 3; estigmas 2-3, estilete glabro, estilopódio cônico, contínuo com o aquênio. Aquênios 1-1,5x0,91,2mm, biconvexos, obovados, pardo-amarelados, superfície reticulada.

Material examinado: BRASIL. Espírito Santo: Laguna de Caraís, I/1996 (fl., fr.), Martins 670 (VIC); Formação Brejo Herbáceo, I/1996 (fl., fr.), Martins 671 (VIC, UFP).

E. mutata pode ser facilmente reconhecida pelo caule trígono ou triquetro e pelo estilopódio contínuo com o aquênio, o que a diferencia de $E$. interstincta, pelo menos ao nível regional. Distribui-se na Laguna de Caraís e no Brejo Herbáceo, onde é abundante. Sua associação a ambientes úmidos de água doce ou salobra é 
confirmada por Adams citado por Davidse et al. (1994); Barros (1960) cita-a para Santa Catarina, e Luceño et al. (1997) para Paraíba e Pernambuco.

\section{Fimbristylis Vahl, Enum. Pl. 2: 285. 1805.}

Ervas anuais ou perenes, cespitosas. Rizomas curtos. Caules geralmente cilíndricos, às vezes aplanados, eretos ou pendentes. Folhas menores que o caule, basais, raramente dísticas, espiraladas, filiformes, aplanadas ou involutas, às vezes liguladas, contralígula ausente. Inflorescências terminais, subumbeliformes, espiguetas sésseis ou pediceladas; glumas helicoidais, curto mucronadas, decíduas, as inferiores estéreis; flores monóclinas, perianto ausente; estames 1-3; estigmas 2-3, estilete geralmente fimbriado, estilopódio decíduo. Aquênios lenticulares ou trígonos, obovóides à orbiculares.

\section{Chave para as espécies de Fimbristylis}

1. Aquênio lenticular, estigmas 2

2. Espiguetas sésseis ou subsésseis, folhas rosuladas 2. F. cymosa

2. Espiguetas pediceladas, folhas não rosuladas 3. F. spadicea 1. Aquênio trígono, estigmas 3 .....1. F. autumnalis

5.1. Fimbristylis autumnalis (L.) Roem. \& Schult., Syst. Veg. 2: 97.1817.

Scirpus autumnalis L., Mant. 2: 180. 1753. Fig. 66-69

Anuais, cespitosas. Caules com até $48 \times 0,15-$ $0,20 \mathrm{~cm}$, achatados, sulcados, eretos, glabros. Folhas geralmente com até $2 / 3$ do comprimento do caule e ca. $1 \mathrm{~mm}$ larg., basais, planas, lanceoladas, antrorsamente escabrosas, glabras, bruscamente afiladas no ápice; bainhas membranáceas, pardas; lígula formada por uma única fileira de pêlos curtos. Inflorescências terminais, fasciculadas, raios $5-10$ até $4 \times 0,1 \mathrm{~cm}$, achatados, antrorsamente escabrosos, glabros, espiguetas 37 xca. $1 \mathrm{~mm}$, ovadas a lanceoladas; glumas $(1,2) 1,5-2 \times c a .1 \mathrm{~mm}$, helicoidais, oval-lanceoladas, mucronadas, pardo-claras; estames 1-2; estigmas 3 , estilete achatado, piloso, estilopódio trígono, caduco. Aquênios 0,4-0,6x0,3-0,4mm, trígonos, obovados, com ângulos definidos, apiculados, pardo-pálidos, superfície lisa.

Material examinado: BRASIL. Espírito Santo: Formação não determinada, s/d, (fl., fr.), Vinha 1387 (VIES).

F. autumnalis caracteriza-se por apresentar folhas com ca. 2/3 do comprimento do caule e com bordos levemente escabrosos. Os exemplares examinados possuem aquênios com superfície lisa; no entanto, essa característica, segundo Kral (1971), varia desde lisa até verrucosa. Outros autores ainda citam-na como tuberculosa (Barros 1960) ou reticulada (Adams citado por Davidse et al. 1994). Kral (1971) comenta também sobre a variação no hábito desta espécie, e sugere que esta variação esteja relacionada com o comprimento do dia e baixas temperaturas. No PEPCV, $F$. autumnalis foi observada apenas nos bordos da formação Brejo Herbáceo; no Brasil foi citada para o Paraná e Santa Catarina (Barros 1960).

5.2. Fimbristylis cymosa R. Br., Prodr.: 228. 1810 .

Fig. 70-73

Perenes, cespitosas. Rizomas $0,1 \mathrm{~mm}$, ramificados. Caules (9)15-24(29)x0,1cm, filiformes, eretos, glabros. Folhas geralmente menores que a metade do comprimento do caule, 1-2mm larg., basais, coriáceas, recurvadas formando uma roseta, com bordos lisos ou raro antrorsamente escabrosos, glabras; bainhas pardas, glabras; lígula e contralígula ausentes. Inflorescências terminais, corimbosas, densas, com raios geralmente menores que $1 \mathrm{~cm}$; brácteas até $1 \mathrm{~cm}, 2-4$, foliosas; espiguetas $4-5 \times 2-3 \mathrm{~mm}$, ovóides, geralmente sésseis em pequenos glomérulos; glumas 1-2x1$1,5 \mathrm{~mm}$, helicoidais, ovado-triangulares, pardas, com bordos membranáceos, translúcidos, decíduas; estames 2; estigmas 2, estilete glabro, estilopódio achatado. Aquênios 0,7-1x0,6-0,8 mm, obovados, biconvexos ou aplanado-convexos, marrons, superfície verrucosa ou lisa.

Material examinado: BRASIL. Espírito Santo: Formação Brejo Herbáceo, IX/1995 (fl., fr.), Martins 709 (VIC); Formação Pós-praia, III/ 93 (fl., fr.), Martins 722 (VIC, UFP); Formação Palmae, V/1996 (fl., fr.), Martins 740 (VIC); 

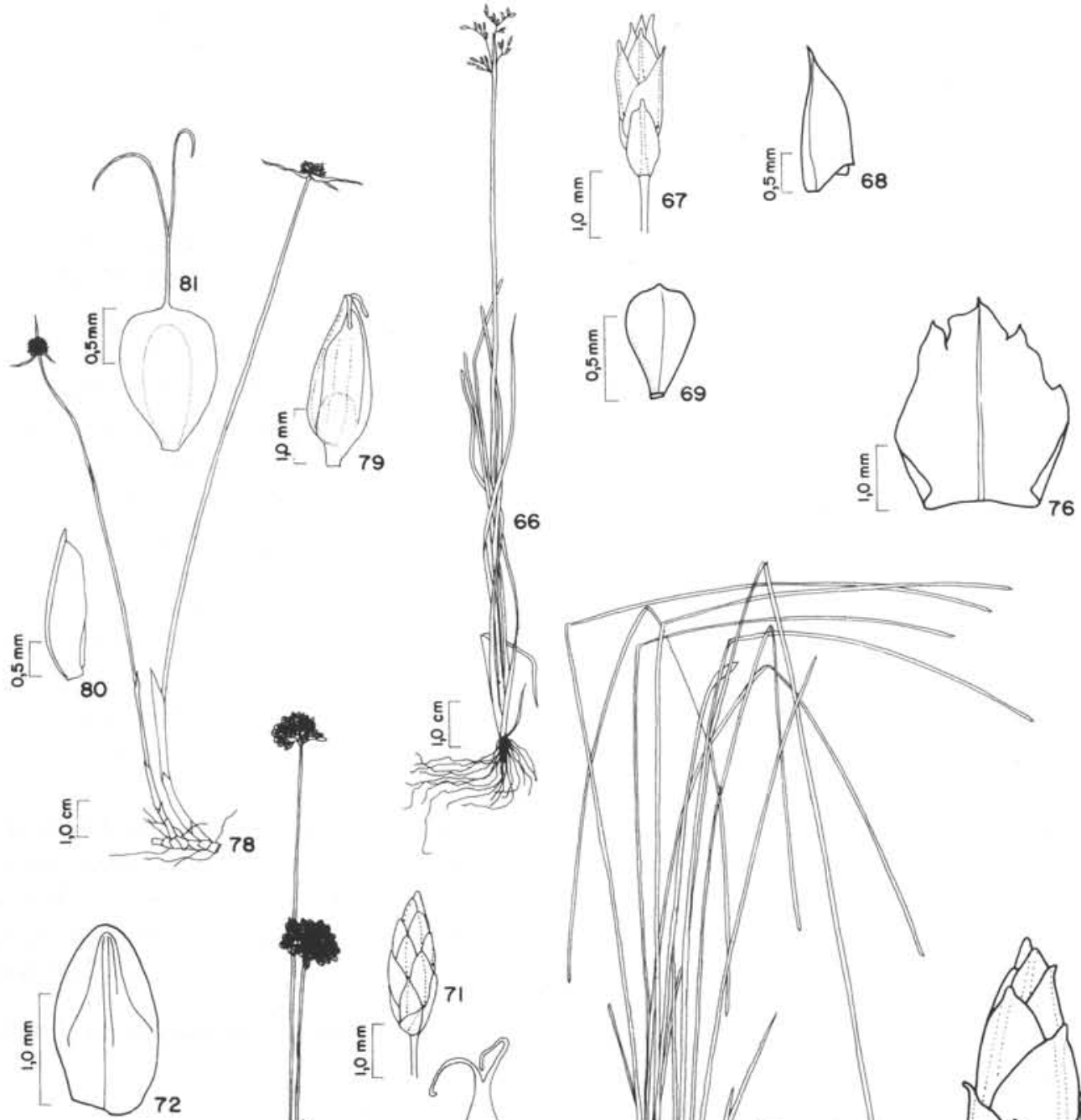

66

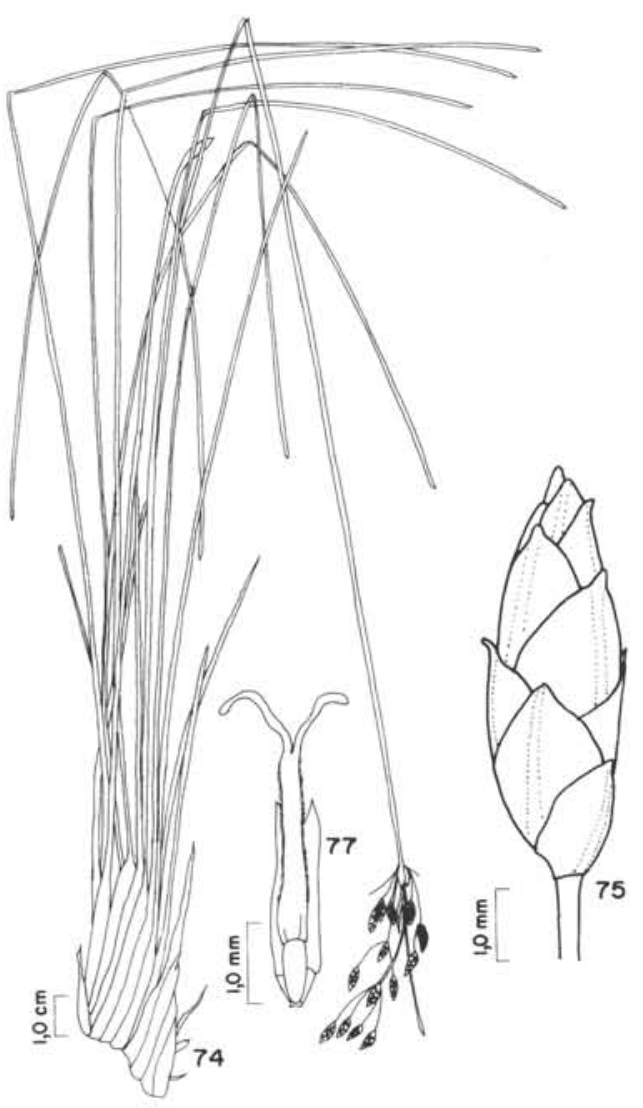

Figuras 66-81. Fimbristylis autumnalis (L.) Roem. \& Schult. 66. Aspecto geral; 67. Espigueta; 68. Gluma; 69. Aquênio (Vinha 1387). Fimbristylis cymosa R. Br. 70. Aspecto geral; 71. Espigueta; 72. Gluma; 73. Aquênio (Martins 722). Fimbristylis spadicea (L.) Vahl. 74. Aspecto geral; 75. Espigueta; 76. Gluma; 77. Flor (Martins 127). Kyllinga vaginata Lam. 78. Aspecto geral; 79. Espigueta; 80. Gluma; 81. Aquênio (Martins 755). 
Formação Pós-praia, V/1996 (fl., fr.), Martins 741 (VIC).

F. cymosa é facilmente caracterizada pelas inflorescências corimbosas a pseudo-umbeliformes com raios curtos, o que confere aspecto bastante denso à inflorescência, e folhas curtas, coriáceas, dispostas geralmente em forma de roseta. A preferência de $F$. cymosa por ambientes salinos é citada por Berghen (1988) e é confirmada no PEPCV onde esta espécie ocorre principalmente em áreas próximas ao mar, como na porção sul da formação Palmae, e na formação Pós-praia, além do Brejo Herbáceo.

5.3. Fimbristylis spadicea (L.) Vahl, Enum. Pl. 2: 294. 1805.

Scirpus spadiceus L., Sp. Pl.: 51. 1753.

Fig. 74-77

Perenes, cespitosas. Rizomas 20-30x2-3mm. Caules 25-50(54)x0,1-0,2cm, cilíndricos a subtrígonos, sulcados, eretos, antrorsamente escabrosos ou não, glabros. Folhas pouco menores que o caule, ca. $2 \mathrm{~mm}$ larg., basais, filiformes, ápice triangular; base mais alargada, pardo-escura e brilhante, secção transversal em "V", antrorsamente escabrosas nos bordos ou não, glabras, com disposição subdística; lígula ausente. Inflorescências terminais, fasciculadas, raios primários até $4,5 \mathrm{~cm}$, achatados, antrorsamente escabrosos nos bordos, brácteas involucrais 2, escabrosas, brilhantes e lisas, a externa com até $6,2 \mathrm{~cm}$ e a interna até $3 \mathrm{~cm}$; espiguetas $1-1,5 \times 0,3-0,5 \mathrm{~cm}$, ovadas a oblongas; glumas $2-3$, ca. $2 \mathrm{~mm}$, ovadas, quilhadas, pardo-escuras, glabras; estames 3 ; estigmas 2, estilete achatado, pardo-claro, piloso nos bordos, com pêlos mais longos na região superior. Aquênios imaturos.

Material examinado: BRASIL. Espírito Santo: Formação Brejo Herbáceo, XI/1991 (fl.), Gomes 1671, (VIES).

F. spadicea apresenta tipicamente folhas com bainhas escuras, de coloração marrom-escuro a negra, brilhantes, e estilete achatado, piloso, sobretudo na porção superior. Foi encontrada apenas na formação Brejo Herbáceo. Esta espécie ocorre em ambientes úmidos, como bordos de rios e pântanos, e algumas vezes ao longo da costa, próximo ao mar (Adams citado por Davidse et al. 1994); foi citada por Barros (1960) para Santa Catarina e Paraná.

6. Fuirena Rottb., Desc. et Ic. Pl.: 70, t. 19. 1773.

Ervas anuais ou perenes, cespitosas. Rizomas de comprimentos variáveis. Caules angulosos, eretos ou pendentes. Folhas basais ou ao longo do caule, oblongo-lanceoladas, glabras ou pubescentes, liguladas; lígulas tubulares; contralígula ausente. Inflorescências terminais ou axilares, em fascículos, panículas ou corimbos compostos; espiguetas ovadas ou elípticas; glumas helicoidais, ovadas, oblongas a obovadas, mucronadas, pilosas, decíduas, as $2-3$ basais estéreis; flores monóclinas, perianto com 3-6 peças, iso ou dimórficas; estames 2-3; estigmas 3 , estilete glabro, estilopódio ausente. Aquênios trígonos ou pentagonais, obovóides, estipitados, com superfície lisa ou finamente estriada.

\section{Chave para as espécies de Fuirena}

1. Perianto composto por seis peças, três cerdas e três lâminas esponjosas 1. F. robusta

1. Perianto composto por três peças laminares e delgadas 2. F. umbellata

\subsection{Fuirena robusta Kunth, Enum. Pl. 2:} 185. 1837.

Fig. $82-88$

Perenes, cespitosas. Rizomas $0,5 \mathrm{~cm}$ diâm., curtos. Caules $60-350(370) \times(0,15) \quad 0,25$ $0,65(1,10) \mathrm{cm}$, cilíndricos, angulosos na porção superior, eretos, glabros. Folhas (7)10 $14(26) \times(0,03) 0,10-0,15 \mathrm{~cm}$, ao longo do caule, oblongo-lanceoladas, coriáceas, de bordos antrorsamente escabrosos, pilosas na superfície adaxial, as inferiores reduzidas a bainhas pardas, cilíndricas, com extremidade oblíqua, apiculada e pilosa; lígula constituída por uma lâmina endurecida, escura e glabra, semi-circundando o caule. Inflorescências terminais e axilares, paniculiformes; espiguetas 3-6(8) x1,2-2(3) mm, ovallanceoladas; glumas $2,8-3,2(3,5) \times(1,8) 2$ $2,2(2,8) \mathrm{mm}$, helicoidais, ovadas a obovadas, com 3 nervuras centrais prolongando-se em um múcron 


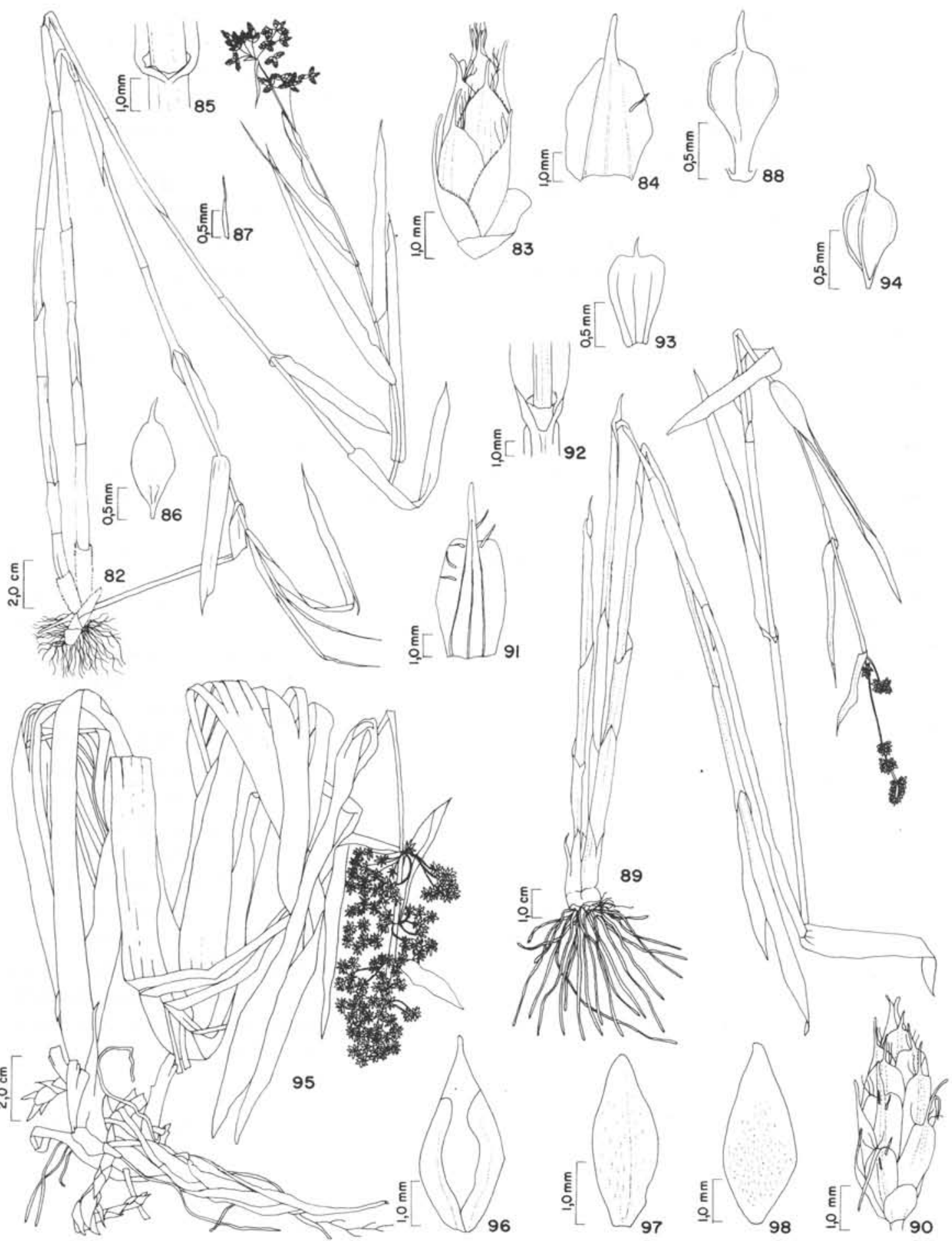

Figuras 82-92. Fuirena robusta Kunth. 82. Aspecto geral; 83. Espigueta; 84. Gluma; 85. Porção distal da bainha; 86. Peça externa do perianto; 87. Peça interna do perianto; 88. Aquênio (Martins 725). Fuirena umbellata Rottb. 89. Aspecto geral; 90 . Espigueta; 91. Gluma; 92. Porção distal da bainha; 93. Peça do perianto; 94. Aquênio (Martins 633). Hypolytrum vericillatum T. Koyama. 95. Aspecto geral; 96. Espigueta; 97. Gluma; 98. Aquênio (Martins 813). 
de até $1 \mathrm{~mm}$, ciliadas nos bordos, com pêlos esparsos e compridos na superfície abaxial; perianto composto por 6 peças, 3 externas, filiformes, ca. $1 \mathrm{~mm}$, e 3 internas, laminares, ca. $2 \mathrm{~mm}$, apiculadas, com 2 sulcos basais, papilosas; estames 3 ; estigmas 3, estilete glabro. Aquênios 1,21,5x0,5-0,8mm, elípticos, triquetros, estipitados e apiculados, superfície lisa.

Material examinado: BRASIL. Espírito Santo: Formação Brejo Herbáceo, III/1996 (fl., fr.), Martins 725 (VIC, UFP); Lagoa Vermelha, VI/1996 (fl., fr.), Martins 750 (VIC); Mata Permanentemente Inundada, XII/1996 (fr.), Martins 808 (VIC).

$F$. robusta diferencia-se de $F$. umbellata por apresentar perianto composto por 6 peças em 2 ciclos e lígula glabra. Ocorre na formação Brejo Herbáceo, nas lagoas Feia e Vermelha e na Mata Permanentemente Inundada. A ocorrência em locais de grande umidade é característica desta espécie (Adams citado por Davidse et al. 1994). F. robusta é citada para Santa Catarina (Barros 1960). Distribui-se principalmente na América tropical até a Argentina e o Paraguai (Barros 1960; Uittien 1966; Adams citado por Davidse et al. 1994).

6.2. Fuirena umbellata Rottb., Desc. Ic. Rar. Pl.: 70. 1773.

Fig. 89-94

Perenes, cespitosas. Rizomas ca. $0,8 \mathrm{~mm}$ diâm., curtos. Caules medindo até $150 \mathrm{~cm}$, com largura de (1)1,5-5(7) mm, pentagonais, eretos, glabros. Folhas (2) $8-20 x(0,3) 0,9-1,6 \mathrm{~cm}$, ao longo do caule, lanceoladas, finamente escabrosas, glabras, as inferiores pardas, reduzidas a bainhas; lígula constituída por uma lâmina membranácea circundando o caule, ciliada na parte posterior. Inflorescências terminais e axilares, em fascículos de glomérulos, sendo os terminais mais desenvolvidos; espiguetas $4-7 \times(1,5) 2 \mathrm{~mm}$, sésseis, elíptico-ovadas; glumas $(2,8) 3 \times 1-1,3 \mathrm{~mm}$, helicoidais, ovadas, obovadas ou oblongas, com três nervuras centrais nítidas que se estendem por um múcron rígido de $1-1,5 \mathrm{~mm}$, com pêlos longos e esparsos na superfície abaxial, e pêlos curtos e densos marginais; perianto com 3 peças mem- branáceas, obovadas, truncadas, aristadas e com três nervuras nítidas; estames 3 ; estigmas 3 , estilete glabro. Aquênios 0,5-1x0,5-0,6mm, obovados, trígonos, com ângulos definidos, estipitados, apiculados, pardo-claros, brilhantes, superfície lisa.

Material examinado: BRASIL. Espírito Santo: Formação Brejo Herbáceo, IX/1995 (fl., fr.), Martins 633 (VIC, UFP).

F. umbellata apresenta caracteristicamente o perianto composto por apenas 3 lâminas membranáceas que revestem o aquênio e lígula ciliada. Sua preferência por áreas alagadas (Adams citado por Davidse et al. 1994) é notável também no PEPCV, onde foram encontrados exemplares apenas na formação Brejo Herbáceo e nas lagoas Feia e Vermelha, assim como F. robusta. No Brasil, ocorre em Santa Catarina e Paraná (Barros 1960).

\section{Hypolytrum Rich., Pers. Syn. 1: 70. 1805.}

Ervas perenes. Rizomas ascendentes ou horizontais. Caules trígonos, eretos ou pendentes. Folhas basais ou ao longo do caule, trinervadas, lineares, ocasionalmente lanceoladas ou oblongas; lígula e contralígula ausentes. Inflorescências terminais, paniculiformes, corimbosas ou umbeliformes, com brácteas foliáceas; espigas com numerosas bractéolas, cada uma com uma espigueta axilar; espiguetas ovadas com ápice agudo, geralmente escabrosas; flores díclinas; perianto com duas lâminas membranáceas; as flores masculinas somente uma ou várias, basais na espigueta, estames 1-2, a flor feminina única, terminal, estigmas 1-2, estilete glabro, estilopódio ausente. Aquênios ovados, obovados ou elípticos, de superfície geralmente rugosa, nus ou envolvidos por um utrículo ao qual estão completamente adnados.

7.1. Hypolytrum verticillatum T. Koyama, Darwiniana 16: 75. 1970.

Fig. 95-98

Perenes. Rizomas até $25 \times 0,5-1,5 \mathrm{~cm}$, recobertos por escamas lanceoladas, pardas a negras. Caules $100-130 \times 0,4-0,5 \mathrm{~cm}$, triquetros, eretos, glabros. Folhas $120-160 \times 2,5-3 \mathrm{~cm}$, predomi- 
nantemente basais, lineares, antrorsamente escabrosas nos bordos e na nervura central, glabras, secção transversal em "M"; lígula e contralígula ausentes. Inflorescências ca. 14xca. $9 \mathrm{~cm}$, terminais, paniculiformes, algumas vezes piramidais, geralmente cilíndricas; espiguetas reunidas em glomérulos globosos a ovados ou piramidais, suspensos por raios que variam de 1 a $4 \mathrm{~cm}$ de comprimento e que estão reunidos em 4 a 6 verticilos ao longo da raque da inflorescência; brácteas com até $50 \times 1,5-2 \mathrm{~cm}$, antrorsamente escabrosas, lisas, cada uma acompanhando um verticilo de raios; flores díclinas; peças do perianto ca. 3 xca. $1 \mathrm{~mm}$, elípticas, pardas, tenuamente ciliadas na face abaxial da nervura central; estames 2; estigma 1, estilete glabro, estilopódio ausente. Aquênio ca. $4 \times 1-2 \mathrm{~mm}$, ovado a oblongo, levemente achatado, ápice esponjoso e pardoclaro, base densamente ponteada e de coloração pardo-escura.

Material examinado: BRASIL. Espírito Santo: Formação Mata Permanentemente Inundada, XII/1996 (fl., fr.), Martins 813 (VIC).

$H$. verticillatum caracteriza-se por apresentar inflorescência vistosa paniculada, com espiguetas reunidas em glomérulos, e aquênios com a porção superior levemente esponjosa, folhas com base purpúrea e rizoma bem desenvolvido. Ocorre no interior da Mata Permanentemente Inundada, juntamente com $F$. robusta e na Mata Periodicamente Inundada. Koyama (1970) cita-a para a restinga de Campos (RJ), às margens da Lagoa Feia. Este é o segundo registro desta espécie, conhecida apenas pela coleção-tipo.

\section{Kyllinga Rottb., Desc. \& Ic.: 12, t. 4. 1773.}

Ervas anuais ou perenes, cespitosas ou reptantes. Rizomas cobertos por escamas. Caules geralmente trígonos, eretos. Folhas basais, lineares, algumas vezes sem lâmina; lígula e contralígula ausentes. Inflorescências terminais, espiciformes, ovóides a cilíndricas, densas; espiguetas comprimidas, decíduas; glumas 2 , quilhadas, dobradas, comumente ciliadas; flores monóclinas, perianto ausente, estames 1-3, estigmas 2, estilete glabro, estilopódio ausente. Aquênios lateralmente comprimidos, com bordos adjacentes à raquila, oblongos a elipsóides, superfície lisa.

8.1. Kyllinga vaginata Lam., Tabl. Encyc. 1: 148.1791.

Fig.78-81

Perenes, reptantes. Rizomas 4-5x0,2-0,5cm, com entre-nós curtos, coberto por escamas. Caules $(6,5) 12-22(33) \times(0,08) 0,1-0,15 \mathrm{~cm}$, trígonos, sulcados, eretos, glabros. Folhas reduzidas a bainhas; bainhas com extremidades agudas, glabras, pardo-purpúreas. Inflorescências 4-10mm diâm., terminais, espiciformes, oblongas, densifloras, com eixo cilíndrico; brácteas 2-4, foliáceas, esparsamente escabrosas nos bordos, glabras; espiguetas 2-3xca. $1 \mathrm{~mm}$, oval-lanceoladas, achatadas, pediceladas; glumas $2-2,4 \times 1,5-1,8 \mathrm{~mm}, 2$ por espigueta, ovadas, curtamente mucronadas, glabras, esverdeadas no centro e hialinas nas laterais; estames 2; estigmas 2, estilete glabro. Aquênios ca. $1 \times 0,6-0,8 \mathrm{~mm}$, biconvexo-comprimidos, obovado-truncados, pardos, negros ou esverdeados, superfície lisa.

Material examinado: BRASIL. Espírito Santo: Formação Pós-praia, III/1996 (fl., fr.), Martins 726 (VIC, UFP); Formação Brejo Herbáceo, VI/1996 (fl., fr.), Martins 755 (VIC).

$K$. vaginata caracteriza-se por apresentar glumas lisas e o eixo da inflorescência cilíndrico. É encontrada na formação Pós-Praia e no Brejo Herbáceo. De acordo com Adams citado por Davidse et al. (1994), esta espécie ocorre principalmente em sítios arenosos, típicos de restinga. No entanto, esse autor não faz qualquer menção à sua ocorrência em áreas alagadas, como observado no PEPCV.

9. Lagenocarpus Nees, Linnaea 9: 304. 1834.

Ervas perenes, geralmente monóicas ou dióicas. Rizomas de comprimento variáveis. Caules eretos ou pendentes. Folhas basais ou ao longo do caule, lineares, em espiral; lígula ausente, contralígula obtusa. Inflorescência composta geralmente por várias panículas corimbosas; em plantas monóicas, os ramos superiores com espiguetas femininas unifloras, solitárias ou 
raramente pareadas; os inferiores com espiguetas masculinas, multifloras; glumas (3-)5-8, perianto geralmente com escamas ou cerdas hipogínicas diminutas, ou nulo, estames 1-2(-6), estigmas 3(4), estilete glabro, estilopódio ausente. Aquênios trígonos ou trilobados.

Chave para as espécies de Lagenocarpus

1. Caule maior que $1,5 \mathrm{~m}$, aquênios trilobados, rugosos 1. L. rigidus

1. Caule menor que $0,5 \mathrm{~m}$, aquênios trígonos, lisos 2. L. verticillatus

9.1. Lagenocarpus rigidus Nees in Mart., Fl. Bras. 2(1): 167. 1842.

Fig. 99-104

Perenes, monóicas. Rizomas ca. $0,6 \mathrm{~mm}$ diâm., coberto por escamas foliáceas pardorosadas. Caules até $210 x(0,15) 0,3-0,4(0,45) \mathrm{cm}$, trígonos, eretos, glabros. Folhas com o comprimento nunca alcançando a inflorescência em indivíduos maduros, e largura de até $4 \mathrm{~cm}$ na base, predominantemente basais, espiraladas, lanceoladas, glaucas, com a base dentada, escabrosa no bordo, glabra, púrpura à pardo-escura; contralígula obtusa à triangular. Inflorescências terminais, paniculiformes; espiguetas femininas terminais, as masculinas basais; glumas $3-4 \times 1,5-2,5 \mathrm{~mm}$, helicoidais, ovadas à obovadas, mucronadas, ciliada no bordo, pardas à pardo-rosadas; estames 2 , rosados e apiculados; estigmas 3, pilosos, estilete curtíssimo, glabro. Aquênios $(1,5) 2,5$ 2,8(3)xca. 1mm, elípticos à ovados, algumas vezes achatados, estipitados, com uma projeção apical parda, obtusa e o corpo trilobado, pardo-amarelado no bordo e verde nos sulcos, superfície rugosa.

Material examinado: BRASIL. Espírito Santo: Formação Brejo Herbáceo, IX/1995 (fl., fr.), Martins 630 (VIC, UFP); Formação Brejo Herbáceo, IX/1995 (fl., fr.), Martins 631 (VIC, UFP).

L. rigidus é facilmente caracterizada pelo seu porte, sempre superior a 1,5 metros, uma inflorescência paniculiforme laxa e folhas predominantemente espiraladas. A taxonomia do complexo $L$. rigidus, $L$. tremulus Nees e $L$. tenuifolius Kuntze, é discutida por Koyama \&
Maguire (1965). A principal característica para a distinção destas espécies baseia-se na folha. $L$. tenuifolius apresenta folhas com largura inferior à $5 \mathrm{~mm}$; L. tremulus apresenta folhas com largura superior à $5 \mathrm{~mm}$, septado-nodosas e geralmente não espiraladas; enquanto que $L$. rigidus possui folhas espiraladas, não septado-nodosas e com largura superior à $5 \mathrm{~mm}$, assim como em nosso material. No PEPCV, L. rigidus distribui-se na formação Brejo Herbáceo, ocorrendo sempre em populações grandes e bastante densas. Sua distribuição abrange as Antilhas, Guianas e o litoral sudeste do Brasil, do sul da Bahia à São Paulo (Koyama \& Maguire 1965).

9.2. Lagenocarpus verticillatus (Spreng.) T. Koyama \& Maguire, Mem. New York Bot. Gard. 12(3): 49. 1965.

Fuirena verticillata Spreng., Nov. Prov.: 47. 1819.

Fig. 105-109

Anuais, cespitosas. Caules 30-45(60)x $(0,06) 0,08-0,12(0,15) \mathrm{cm}$, trígonos, raramente sulcados, pendentes, glabros. Folhas (8)15$22(36) \times 0,2-0,3 \mathrm{~cm}$, predominantemente basais, lineares, finamente antrorsamente escabrosas nos bordos, glabras; contralígula deltóide a obtusa. Inflorescências constituídas por um eixo com 3-5 fascículos laterais com 5-10 espiguetas; espiguetas 3-5x0,6-1 mm, oval-oblongas; glumas 3-5 x0,8$1,5 \mathrm{~mm}$, helicoidais, obovadas, mucronadas, glabras, pardo-purpúreas; nas espiguetas femininas somente 3 , nas masculinas inúmeras; flores monóclinas, perianto ausente; estames 2 ; estigmas 3, pilosos, estilete curtíssimo, glabro. Aquênios ca. $2 \times 1 \mathrm{~mm}$, trígonos, com bordos definidos, obovados, estipitados, levemente apiculados a truncados, trissulcado na base, pardo-purpúreos, superfície ponteada.

Material examinado: BRASIL. Espírito Santo: Formação Aberta de Clusia, IX/1995 (fl., fr.), Martins 643 (VIC, UFP); Formação Aberta de Ericaceae, VI/1996 (fl., fr.), Martins 749(VIC).

L. verticillatus é diferenciada de L. rigidus, em campo, tanto pelo porte quanto pelo habitat. Raramente excede aos $40 \mathrm{~cm}$ compr. e está distribuída exclusivamente na região de entre- 

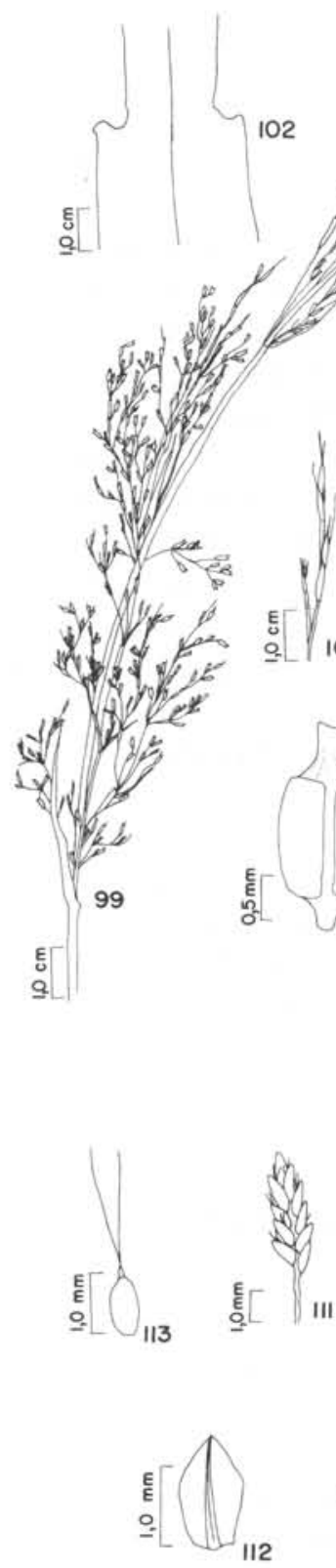
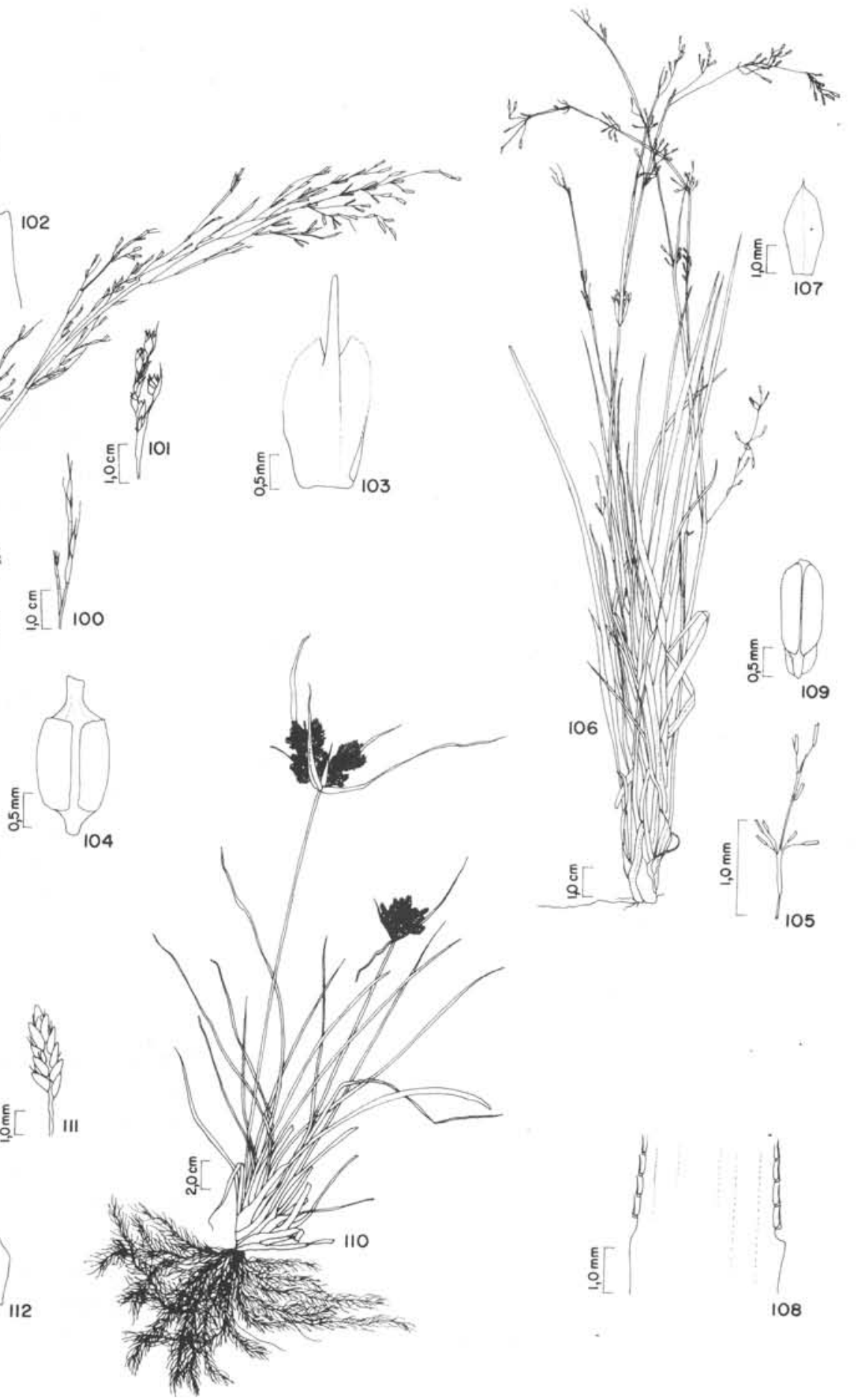

Figuras 99-113. Lagenocaarpus rigidus Nees. 99. Aspecto geral; 100. Detalhe da inflorescência feminina; 101. Detalhe da inflorescência masculina; 102. Porção distal da bainha; 103. Gluma; 104. Aquênio (Martins 632), Lagenocarpus verticillatus (Spreng.) T. Koyama \& Maguire. 105. Aspecto geral; 106. Detalhe da inflorescência; 107. Gluma; 108. Porção distal da bainha; 109. Aquênio (Martins 787). Pycreus polystachyos P. Beauv. 110. Aspecto geral; 111. Espigueta; 112. Gluma; 113. Aquênio (Martins 688). 
moitas das formações abertas de Clusia e Ericaceae. Além disso, apresenta aquênio oblongo, trígono, com a superfície lisa, enquanto em $L$. rigidus o aquênio é fortemente trilobado e com a superfície rugosa. $L$. verticilatus distribuise pelo norte da América do Sul, Guianas, Suriname, Colômbia, Venezuela e Brasil, no Amapá, Pará, Goiás, Rio de Janeiro e Minas Gerais (Koyama \& Maguire 1965). Foi examinado um exemplar de L. verticillatus coletado no Estado da Bahia, depositado no herbário VIES.

10. Pycreus P. Beauv., Fl. Owar. 2: 48, t. 86. 1807.

Ervas anuais ou perenes, cespitosas. Caules triquetros, eretos, lisos. Folhas basais, lineares; lígula e contralígula ausentes. Inflorescências terminais, umbeliformes, glomérulos ou fascículos; espiguetas lineares ou oblongas, mais ou menos comprimidas, laxas ou densas; glumas dísticas, freqüentemente 2-carinadas, decíduas; flores monóclinas, perianto ausente; estames 1-3; estigmas 2, estiletes glabros, estilopódio ausente. Aquênios lenticulares, geralmente biconvexos, com o bordo adjacente à raquila, superfície levemente reticulada ou ponteada.

10.1. Pycreus polystachyos P. Beauv., Fl. Owar. 2: 48, t. 86. 1807.

Cyperus polystachyos Rottb., Desc. Pl. Rar.: 21. 1772.

Fig. 110-113

Perenes, cespitosas. Rizomas curtos. Caules (29) $50-90 \times 0,1-0,2 \mathrm{~cm}$, trígonos, eretos, glabros. Folhas $15-45 \times 0,2-0,3 \mathrm{~mm}$, basais, lineares, levemente escabrosas ou não, glabras. Inflorescências umbeliformes, raios (0)4-8, até $3,5 \mathrm{~cm}$; espiguetas 6-20x1-2mm, lanceoladas, comprimidas, em fascículos triangulares; brácteas foliáceas, até $29 \mathrm{~cm}$; glumas 1,2-1,5x0,6-1 mm, dísticas, ovadas, quilhadas, verde-amareladas, decíduas; estames 2; estigmas 2, estilete glabro, estilopódio ausente. Aquênios 0,7-0,9x0,3-0,4mm, oblongos, lenticulares, apiculados, pardoamarelados a escuros, superfície ponteada.

Material examinado: BRASIL. Espírito Santo: Formação Aberta de Clusia, IX/1995 (fl., fr.), Martins 642 (VIC, UFP); Formação Brejo Herbáceo, I/1996 (fl., fr.), Martins 688 (VIC, UFP); Formação Mata Seca, V/1996 (fl., fr.), Martins 734 (VIC); Lagoa Vermelha, VIII/1996 (fl., fr.), Martins 779 (VIC).

$P$. polystachyos caracteriza-se por sua inflorescência fasciculada ou umbeliforme com glumas amareladas a amarelo-amarronzadas. Embora essa coloração seja bastante típica, a inflorescência e o porte são bastante variáveis. Essas variações foram observadas por Barros (1960) e Koyama (1979) que mencionam o porte variando entre 5 e $80 \mathrm{~cm}$. Tucker (1994) comenta que a grande variação morfológica de $P$. polystachyos tem ocasionado o aumento do número de espécies, e entendimento adequado destas variações seria alcançado com revisão do gênero. $P$. polystachyos distribui-se exclusivamente em terrenos úmidos mas não encharcados, principalmente no bordo da formação Brejo Herbáceo e em áreas alteradas, onde são formadas poças d'água. Adams citado por Davidse et al. (1994) e Scholz \& Scholz (1983) citam esta espécie para regiões de terreno arenoso costeiro, como dunas e áreas úmidas arenosas; no Brasil, há registros para Santa Catarina, Rio Grande do Sul (Barros 1960), Paraíba, Pernambuco (Luceño et al. 1997), Rio de Janeiro e Bahia (Nees 1842).

11. Remirea Aubl., Hist. Pl. Gui. 1: 44. t. 16. 1775.

11.1. Remirea maritima Aubl., Hist. Pl. Gui. 1: 45 , t. 16.1775 .

Fig. 114-118

Perenes, reptantes. Rizomas longos, ca. $0,5 \mathrm{~cm}$ diâm., com entre-nós até $10 \mathrm{~cm}$, coberto por bainhas pardas. Caules até $15 \mathrm{~cm}$ compr., algumas vezes ramificados, com a parte inferior semelhante ao rizoma e a parte superior totalmente recoberta pelas folhas, eretos. Folhas $25-50 \times 4-7 \mathrm{~mm}$, ao longo do caule, com disposição helicoidal, glabras, lanceoladas, coriáceas, canaliculadas, com ápice ligeiramente mucronado, espinhoso, bordos antrorsamente escabrosos; bainhas purpúreas. Inflorescências 1-1,5x0,7-1,2 mm, terminais, espiciformes, densas, acompanhadas por brácteas 


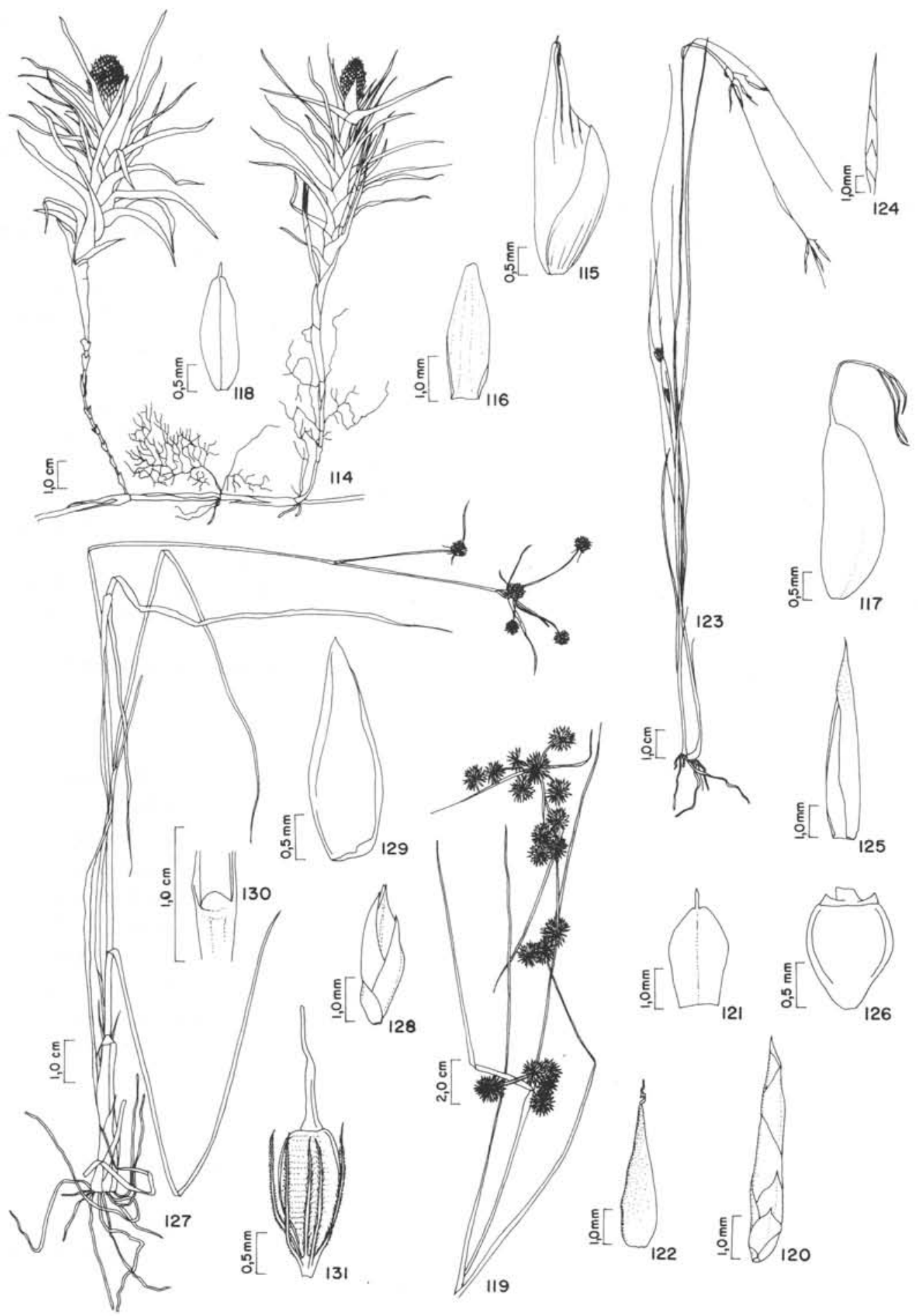

Figuras 114-131. Remirea maritima Aubl. 114. Aspecto geral; 115. Espigueta; 116. Gluma; 117. Aquênio envolvido pela gluma esponjosa; 118. Aquênio (Martins 673). Rhynchospora exaltata Kunth. 119. Aspecto geral; 120. Espigueta; 121. Gluma; 122. Aquênio (Martins 744), Rhynchospora filiformis Vahl. 123. Aspecto geral; 124. Espigueta; 125. Gluma; 126. Aquênio (Martins 679). Rhynchospora holoschoenoides (Rich.) Herter. 127. Aspecto geral; 128. Espigueta; 129. Gluma; 130. Porção distal da bainha; 131. Aquênio (Martins 639). 
foliáceas de número variado, oblongo-piramidais; espiguetas 4-4,3×1-1,5mm, ovadas a obovadas, pontiagudas; glumas 3 por espigueta, ovadas e apiculadas, a inferior, $3,0-3,2 \times 1,5-2,5 \mathrm{~mm}$, e a mediana, ca. $4 \times 2-3 \mathrm{~mm}$, estéreis, pardo-claras e paleáceas, e a superior, envolvendo o aquênio, esponjosa, inchada, firme e albo-rosada; estames 3 ; estigmas 3 , estilete glabro, estilopódio ausente. Aquênios 2-2,3×0,6-0,8 mm, oblongos, trígonos, com um lado maior que os demais, pardo, superfície lisa.

Material examinado: BRASIL. Espírito Santo: Formação Psamófila-reptante, I/1996 (fl., fr.), Martins 673 (VIC, UFP); Formação não determinada, VI/1988 (fl., fr.), Fabris 413 (VIES).

$R$. maritima caracteriza-se facilmente pela forma de crescimento rizomatoso e folhas coriáceas pontiagudas dispostas em roseta. Em trabalhos florísticos do PEPCV, R. maritima foi tratada como Mariscus pedunculatus (Pereira et al. 1992; Fabris et al. 1990). No PEPCV, distribuise sempre próxima ao mar, em áreas expostas ao sol e até mesmo em contato com a água do mar, como na formação Halófila. Este habitat é típico desta espécie (Koyama 1979; Adams citado por Davidse et al. 1994).

12. Rhynchospora Vahl, Enum. Pl. 2: 229. 1806.

Ervas anuais ou perenes. Rizomas com comprimento variável. Caules de comprimento e forma bastante variáveis, geralmente eretos. Folhas predominantemente basais, filiformes a lineares, algumas vezes escabrosas, geralmente glabras; lígula e contralígula geralmente ausentes. Inflorescências terminais ou axilares, em glomérulos, corimbosas ou fasciculadas; espiguetas sésseis ou pediceladas, ovóides ou lanceoladas, 1 a plurifloras; glumas helicoidais ou subdísticas, as 2-5 inferiores estéreis; flores monóclinas ou díclinas masculinas, as basais sempre monóclinas, as terminais monóclinas ou masculinas; perianto composto por 0-6(-20) cerdas; estames 1-3(-12); estigmas 1-2, estilete curto, glabro, estilopódio persistente. Aquênios lenticulares a globosos.
Chave para as espécies de Rhynchospora

1. Aquênios com cerdas hipogínicas

2. Espiguetas sésseis

3. Estilopódio robusto, base tão larga quanto o aquênio ......................... 3. R. gigantea

3. Estilopódio delgado, base com cerca de metade da largura do aquênio

\section{4. $R$. holoschoenoides}

2. Espiguetas pediceladas

4. Estilopódio triangular alongado, maior que $0,9 \mathrm{~mm}$ 5. $R$. marisculus

4. Estilopódio triangular curto, menor que $0,8 \mathrm{~mm}$ 6. R. rugosa

1. Aquênios sem cerdas hipogínicas

5. Espiguetas reunidas em glomérulos densos e globosos 1. $R$. exaltata

5. Espiguetas em corimbos ou pseudo-umbelas 6. Planta perene 2. $R$. filiformis

6. Planta anual

7. Estilopódio tridentado ... 7. R. tenerrima

7. Estilopódio sem dentes ....8. R. tenuis

12.1. Rhynchospora exaltata Kunth, Enum. Pl. 2: 291. 1837.

Fig. 119-122

Perenes, cespitosas. Rizomas ca. $0,5 \mathrm{~cm}$ diâm. Caules até $90 \times 0,20-0,40 \mathrm{~cm}$, trígonos, eretos, glabros. Folhas pouco mais longas que o caule, com 0,5-0,9mm larg., predominantemente basais, lanceoladas, antrorsamente escabrosas, glabras; lígula e contralígula ausentes. Inflorescências terminais e axilares, geralmente paniculiformes; espiguetas 4-5xca. $1 \mathrm{~mm}$, oval-lanceoladas, reunidas em 1-3 glomérulos globosos por raio, com ca. $1 \mathrm{~cm}$ diâm., acompanhados por uma bráctea foliácea até $30 \mathrm{~cm}$ compr.; glumas 2-4x1$2 \mathrm{~mm}$, helicoidais, ovadas a obovadas, mucronadas, glabras, pardo-pálidas; estames 3; estigmas 2 , estilete glabro, estilopódio longo-triangular. Aquênios 2,5-3,5×0,3-0,5 mm, lenticulares, pardos, superfície levemente rugosa.

Material examinado: BRASIL. Espírito Santo: Formação Mata Seca, V/1996 (fl.), Martins 744 (VIC); Formação Mata Seca, XII/1996 (fl., fr.), Martins 812 (VIES).

R. exaltata caracteriza-se pela inflorescência paniculada com 2-7 glomérulos globosos, com ca. 
$1 \mathrm{~cm}$ diâm., e espiguetas pardo-amareladas. É a única espécie de Rhynchospora ocorrente na formação Mata Seca, e não na formação Brejo Herbáceo, como as demais. Thomas citado por Davidse et al. (1994) comenta sobre sua preferência por solos arenosos ou graníticos. A espécie é citada para Minas Gerais, São Paulo, Santa Catarina e Rio de Janeiro; está praticamente restrita à América do Sul, ocorrendo desde as Guianas e Venezuela até o Paraguai e Cuba (Barros 1960; Thomas citado por Davidse et al. 1994).

12.2. Rhynchospora filiformis Vahl, Enum. Pl. 2: 232. 1805.

Fig. 123-126

Perenes. Rizomas $1 \mathrm{~mm}$ diâm. Caules (12) $30-40 \times 0,02-0,05 \mathrm{~cm}$, triquetros, eretos a levemente pendentes, glabros. Folhas (9)25$30(35) \times 0,02-0,05(0,07) \mathrm{cm}$, predominantemente basais, filiformes, glabras; lígula e contralígula ausentes. Inflorescências terminais (1) e axilares (1-2), paniculiformes; espiguetas 2-6, 8-12x1$1,2 \mathrm{~mm}$, pediceladas, oval-lanceoladas; glumas 6$7 \times 2-3,5 \mathrm{~mm}$, helicoidais, ovadas a obovadas, levemente mucronadas, pardo-amareladas; flores monóclinas, perianto ausente; estames 3; estigmas 1, estilete glabro, estilopódio deprimido, com duas projeções curtas, laterais e uma mais longa e escura, mediana. Aquênios 11,4 $\times 0,9-1,2 \mathrm{~mm}$, lenticulares, elípticos ou obovados, estipitados, pardos, com uma mancha escura central, superfície papilosa.

Material examinado: BRASIL. Espírito Santo: Formação Brejo Herbáceo, I/1996 (fl., fr.), Martins 679 (VIC).

R. filiformis caracteriza-se por possuir aquênios com superfície lisa e espiguetas de comprimento geralmente maior que $8 \mathrm{~mm}$. No PEPCV, encontra-se na formação Brejo Herbáceo, geralmente em áreas onde o nível da água não é muito elevado. Sua ocorrência neste tipo de ambiente é mencionada por Thomas citado por Davidse et al. (1994) que ainda inclui entre seus habitats preferenciais, savanas e poças temporárias. Este é o primeiro registro de $R$. filiformis para o Brasil. Distribui-se pela América tropical
(Thomas citado por Davidse et al. 1994) e Antilhas (Thomas 1992),

12.3. Rhynchospora gigantea Link, Jarhb. Gewächsk. 1: 76. 1820 .

Fig. 132-135

Perenes, cespitosas. Rizomas curtos. Caules até $150 \times 0,2-0,4 \mathrm{~cm}$, trígonos, eretos, glabros. Folhas até $100 \times 0,5-2,1 \mathrm{~cm}$, predominantemente basais, lanceoladas, antrorsamente escabrosas, sobretudo na região superior, glabras, esponjosas na base, levemente septadas; lígula e contralígula ausentes. Inflorescências terminais (1) e axilares (1-4), umbeliformes, raios primários até $3 \mathrm{~cm}$, raios secundários até $2 \mathrm{~cm}$, achatados, glabros; espiguetas 5-6(7,5)x1-1,2 mm, oval-lanceoladas, pardas; glumas 2-6x1,5-3mm, helicoidais, ovadas, levemente apiculadas, glabras; flores monóclinas, perianto com 6-7 cerdas antrorsamente escabrosas, mais longas que o aquênio, porém, geralmente mais curtas que o estilopódio; estames 3 ; estigma 1, estilete glabro, estilopódio $(1,5) 2-2,5(2,8) x c a$. $1 \mathrm{~mm}$, cônico, sulcado, pardo-claro. Aquênios 2$2,2(2,8) x c a .1 \mathrm{~mm}$, obovados a oblongos, pardoescuros, margens levemente proeminentes, superfície reticulada.

Material examinado: BRASIL. Espírito Santo: Formação Brejo Herbáceo, I/1996 (fl., fr.), Martins 676 (VIC, UFP); Formação Brejo Herbáceo, I/1996 (fl., fr.), Martins 691 (VIC, UFP).

$R$. gigantea caracteriza-se pelo porte, geralmente acima de $1,5 \mathrm{~m}$, pela inflorescência corimbosa com grande número de espiguetas e folhas septado-nodosas, com textura esponjosa, pelo menos na base. Está restrita à formação Brejo Herbáceo, principalmente nos bordos. Thomas citado por Davidse et al. (1994) confirma a preferência desta espécie por ambientes com maior umidade, tais como pântanos e savanas úmidas. R. gigantea é citada para Santa Catarina (Barros 1960). Distribui-se nas Antilhas e Américas, da Mesoamérica ao sul do Brasil (Thomas 1992).

\subsection{Rhynchospora holoschoenoides} (Rich.) Herter, Rev. Sudamer. Bot. 9: 157. 1953. Schoenus holoschoenoides Rich., Act. Soc.

Hist. Nat. Par. 1: 106. 1792.

Fig. 127-131 


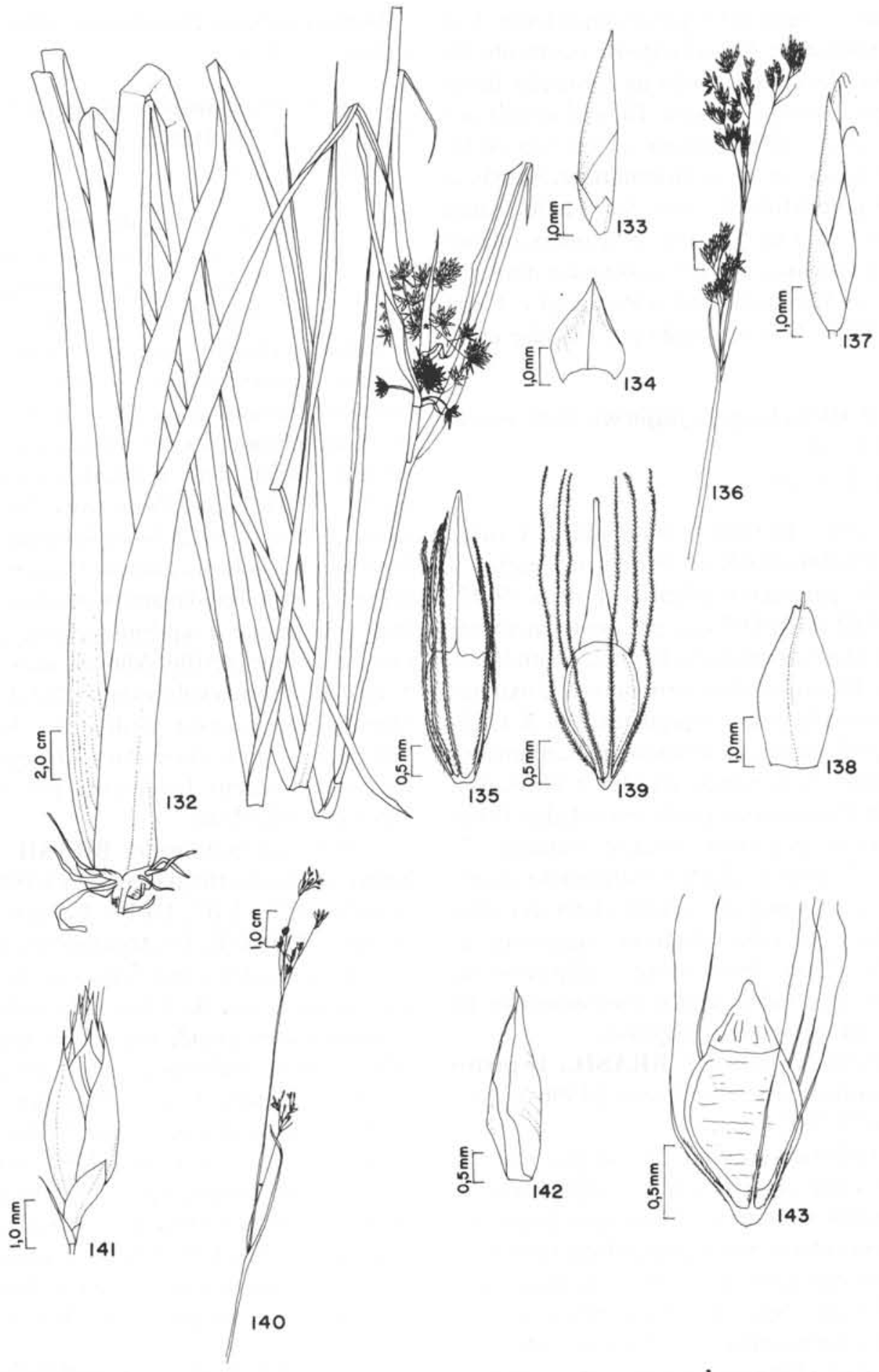

Figuras 132-143. Rhynchospora gigantea Link. 132. Aspecto geral; 133. Espigueta; 134. Gluma; 135. Aquênio (Martins 691). Rhynchospora marisculus Lindl. \& Nees. 136. Aspecto geral; 137. Espigueta; 138. Gluma; 139. Aquênio (Martins 635). Rhynchospora rugosa (Vahl) Gale. 140. Inflorescência; 141. Espigueta; 142. Gluma; 143. Aquênio (Martins 753). 
Perenes, cespitosas. Rizomas curtos. Caules (20)50-95x0,1-0,35cm, trígonos, sulcados, com base robusta, eretos, antrorsamente escabrosos nos ângulos, glabros. Folhas pouco menores que o caule, (2)3-5(6) cm larg., predominantemente basais, linear-lanceoladas, antrorsamente escabrosas, glabras; lígula e contralígula ausentes. Inflorescências terminais (1) e axilares (1), constituídas por 1 glomérulo séssil, basal, e 2-4 radiados, globosos, (6)7-9mm, algumas vezes com 2 raios secundários, perpendiculares ao primeiro, cada um com um glomérulo terminal; espiguetas $2-4 x c a$. $1 \mathrm{~mm}$, ovadas a oval-lanceoladas; glumas 2,2-4x1,6-2,5mm, helicoidais, ovadas, pardoamareladas; perianto com 6 cerdas antrorsamente escabrosas, algumas vezes uma mais reduzida que as demais; estames 3; estigma 1, estilete glabro, estilopódio 0,8-1,6mm, cônico-estreito. Aquênios 1-1,5x0,6-0,9mm, obovados, estipitados, com bordos definidos, superfície reticulada.

Material examinado: BRASIL. Espírito Santo: Formação Brejo Herbáceo, IX/1995 (fl., fr.), Martins 639 (VIC, UFP); Formação Brejo Herbáceo, VIII/1996 (fl., fr.), Martins 798 (VIC).

$R$. holoschoenoides caracteriza-se por apresentar espiguetas dispostas em glomérulos com ca. $8 \mathrm{~mm}$ diâm., de número variável, radiados ou sésseis. Está restrita à formação Brejo Herbáceo, seja em seu bordo ou em áreas mais alagadas no seu interior. De acordo com Thomas, (1992) distribui-se na África e América Tropical, do México ao sul do Brasil restringindo-se às savanas, pântanos e áreas perturbadas.

\subsection{Rhynchospora marisculus Lindl. \&} Nees in Mart., Fl. Bras. 2(1): 142. 1842.

Fig. 136-139

Perenes, cespitosas. Rizomas curtos. Caules até $130 \times 0,1-0,3 \mathrm{~cm}$, trígonos, eretos a levemente pendentes, glabros. Folhas $45-78 \times 0,3-0,5 \mathrm{~cm}$, basais e ao longo do caule (2-3), linear-lanceoladas, glabras. Inflorescências terminais (1) e axilares (1-2), paniculadas; espiguetas 4-5x(0,7)1$1,3 \mathrm{~mm}$, lanceoladas; glumas 4-5x1-2mm, helicoidais, ovadas, pardo-escuras a ferrugíneas; perianto com 6 cerdas antrorsamente escabrosas, geralmente ultrapassando o ápice do estilopódio; estame 1; estigmas 2, estilete glabro, estilopódio (0,8)1,2-1,8mm, longo-triangular, pardo-escuro. Aquênios 1,1-1,5x0,7-1 mm, elípticos a obovados, lenticulares, com bordos definidos, levemente estipitados, amarelo-esverdeados, superfície transversalmente rugosa.

Material examinado: BRASIL. Espírito Santo: Formação Brejo Herbáceo, IX/1996 (fl., fr.), Martins 635 (VIC).

$R$. marisculus diferencia-se de $R$. rugosa basicamente pelo comprimento e formato do estilopódio, e pelo comprimento das cerdas periânticas. $\operatorname{Em} R$. marisculus, o estilopódio mede de 0,9 a $2,2 \mathrm{~mm}$ e é longo-triangular, enquanto em $R$. rugosa ele mede de 0,5 a $0,8 \mathrm{~mm}$ e sua forma se aproxima de um triângulo equilátero. As cerdas periânticas de $R$. marisculus raramente ultrapassam o ápice do estilopódio, enquanto em $R$. rugosa elas freqüentemente são bem mais longas. $R$. marisculus encontra-se apenas na formação Brejo herbáceo. Guaglianone (1979) comenta a preferência desta espécie por locais pantanosos, ácidos, onde Cyperaceae e Poaceae são dominantes, além de rios, baixadas arenoso-pedregosas e restingas. Sua distribuição abrange as Américas, onde ocorre do norte da América do Sul até o Paraguai e Argentina, sendo comum também na faixa litorânea sul do Brasil e do Uruguai e nas Antilhas (Thomas 1992; Guaglianone 1979).

\subsection{Rhynchospora rugosa (Vahl) Gale,} Rhodora 46: 275. 1944. 1798.

Schoenus rugosus Vahl, Eclog. Am. 2: 5.

Fig. 140-143

Perenes, cespitosas. Rizomas 1-2mm diâm. Caules 55-95x(0,06)0,1-0,2cm, trígonos, eretos a levemente pendentes, glabros. Folhas (21)26,5$32 \times(0,1) 0,18-0,25(0,3) \mathrm{cm}$, predominantemente basais, linear-lanceoladas, glabras; lígula e contralígula ausentes. Inflorescências terminais (1) e axilares (1-3), paniculiformes; espiguetas3-4x1$1,8 \mathrm{~mm}$, ovadas; glumas $3-4 \times 2-2,2 \mathrm{~mm}$, helicoidais, ovadas, levemente apiculadas, pardo-ferrugíneas; flores monóclinas, perianto com 6 cerdas antrorsamente escabrosas, com pelos pouco mais longos na base; estame 1; estigmas 2 , estilete 
glabro, estilopódio $0,5-0,6 \mathrm{~mm}$, triangular, escuro. Aquênios 1,1-1,3x0,9-1,1 mm, elípticos a levemente obovados, lenticulares, estipitados, bordos definidos, amarelo-esverdeado, superfície rugosa.

Material examinado: BRASIL. Espírito Santo: Formação Brejo Herbáceo, VI/1996 (fl., fr.), Martins 753 (VIC).

$R$. rugosa diferencia-se de $R$. marisculus basicamente pelo comprimento e formato do estilopódio, como colocado anteriormente para $R$. marisculus. De acordo com Guaglianone (1979) R. rugosa é caracterizada por seus aquênios obpiriformes com superfície rugosa e pelo estilopódio com bordos antrorsamente escabrosos. Os exemplares de $R$. rugosa não apresentaram estilopódio escabroso e as cerdas do perianto ultrapassaram o comprimento do aquênio, ao contrário do citado por Guaglianone (1979), no entanto, o formato e o comprimento do estilopódio são típicos. No PEPCV, R. rugosa foi encontrada somente na formação Brejo Herbáceo, principalmente nos bordos. Distribui-se pelo continente americano, do México até a Argentina, incluindo o litoral sudeste brasileiro, e sua ocorrência está relacionada com solos úmidos, savanas argilosas e matas de galeria (Guaglianone 1979).

12.7. Rhynchospora tenerrima Nees ex Spreng., Syst. Veg. 4: 26. 1827.

Fig. 144-147

Anuais, cespitosas. Caules até $30 \times 0,2 \mathrm{~cm}$, trígonos, levemente sulcados, eretos a levemente pendentes, glabros. Folhas de comprimento semelhante ao do caule, ca. $0,3 \mathrm{~mm}$, predominantemente basais, involutas, glabras; lígula e contralígula ausentes. Inflorescências terminais (1) e axilares (2-3), corimbosas, ca. $7 \mathrm{~mm}$, acompanhada por uma bráctea filiforme do mesmo comprimento, oval-lanceoladas; espiguetas 4,56 xca. $1 \mathrm{~mm}$, ovadas; glumas $2-4(4,5)$ xca. $2 \mathrm{~mm}$, helicoidais, ovadas, pardas; perianto ausente; estames 3; estigmas 2, estilete glabro, estilopódio variavelmente tridentado. Aquênios 1,5-2x1$1,5(1,8) \mathrm{mm}$, orbiculares a obovados, levemente estipitados, pardo-claros, acinzentados ou esbranquiçados, superfície rugosa.
Material examinado: BRASIL. Espírito Santo: Formação Brejo Herbáceo, VIII/1996 (fl., fr.), Martins 801 (VIC).

$R$. tenerrima, embora seja semelhante a algumas formas de $R$. tenuis, pode ser facilmente diferenciada por possuir o estilopódio do aquênio tipicamente tridentado, com o dente mediano maior que os laterais. $R$. tenerrima ocorre apenas na formação Brejo Herbáceo, principalmente nos bordos. Thomas (1992) cita-a para ambientes bastante semelhantes ao Brejo Herbáceo, como pântanos, savanas úmidas e poças temporárias. Sua distribuição abrange as Antilhas e a América do Sul, na Bolívia e no Brasil (Thomas citado por Davidse et al. 1994).

12.8. Rhynchospora tenuis Link, Jarhb. Gewächsk. 1: 76. 1820.

Fig. 148-151

Perenes, cespitosas. Rizomas curtos, até $3 \mathrm{~mm}$ diâm. Caules (12)18-23(31)x0,03-0,1cm, trígonos, eretos a levemente pendentes, glabros. Folhas de comprimento semelhante ao do caule, ca. $0,8 \mathrm{~mm}$ larg., predominantemente basais, filiformes, glabras. Inflorescências terminais (1) e axilares (1-2), corimbosas; espiguetas 4-5x0,7$1 \mathrm{~mm}$, oval-lanceoladas; glumas $(2,2) 2,7$ $3,5 \times(1) 1,3-1,5(2) \mathrm{mm}$, helicoidais, ovadas ou obovadas, glabras, pardas, as inferiores menores, mucronadas e translúcidas; flores monóclinas, perianto ausente; estames 3 ; estigmas 2 , estilete glabro, estilopódio deprimido, triangular, algumas vezes contínuo com o bordo do aquênio. Aquênios 0,8-1 $\times 0,6-0,7 \mathrm{~mm}$, obovados ou orbiculares, pardo-claros a pardo-escuros, com poucas e nítidas rugas na superfície.

Material examinado: BRASIL. Espírito Santo: Formação Brejo Herbáceo, IX/1995 (fl., fr.), Martins 638 (VIC); Formação Aberta de Clusia, I/1996 (fl., fr.), Martins 695 (VIC); Formação Brejo Herbáceo, I/1996 (fl., fr.), Martins 703 (VIC).

$R$. tenuis diferencia-se de $R$. tenerrima pelo formato do estilopódio, que geralmente é deltóide deprimido e levemente bilobado, enquanto em $R$. tenerrima ele é notoriamente tridentado. 


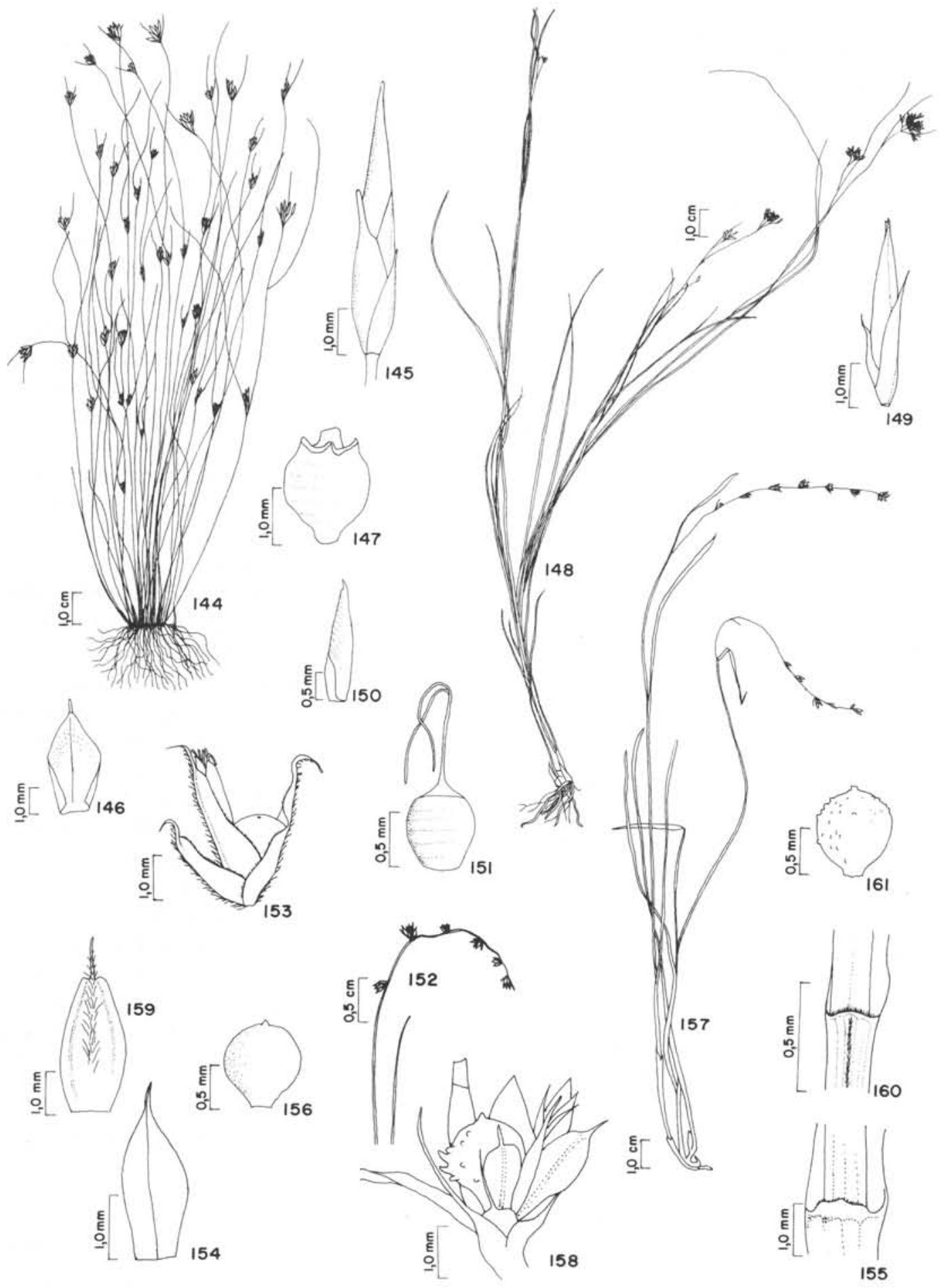

Figuras 144-161. Rhynchopora tenerrima Nees ex Spreng. 144. Aspecto geral; 45. Espigueta; 146. Gluma; 147. Aquênio (Martins 801). Rhynchospora tenuis Link. 148. Aspecto geral; 149. Espigueta; 150. Gluma; 151. Aquênio (Martins 638). Scleria hirtella Sw. 152. Detalhe da inflorescência; 153. Espigueta; 154. Gluma; 155. Porção distal da bainha; 156. Aquênio (Martins 674). Scleria interrupta Rich. 157. Aspecto geral; 158. Espigueta; 159. Gluma; 160. Porção distal da bainha; 161. Aquênio (Martins 727). 
Ocorre na formação Brejo Herbáceo e na formação aberta de Clusia, onde é a única representante do gênero. Thomas citado por Davidse et al. (1994) refere sua ocorrência em pastagens abertas ao longo de córregos ou rios, e em altitudes sempre acima de $800 \mathrm{~m}$. No Brasil, há registros para Santa Catarina e Paraná (Barros 1960). Está amplamente distribuída na América, do México à Argentina, ocorrendo também nas Antilhas (Thomas 1992).

13. Scleria P. J. Bergius, Vet. Acad. Handl. t. $4,5: 142.1765$.

Ervas perenes ou anuais, cespitosas. Rizomas bem desenvolvidos nas espécies perenes. Caules triquetros, eretos ou escandentes, escabrosos. Folhas basais e ao longo do caule, lineares, escabrosas, glabras; bainhas algumas vezes aladas; lígula ausente, contralígula comumente desenvolvida. Inflorescências terminais ou axilares, piramidais, fasciculadas, espiciformes ou virgatas; espiguetas com flores díclinas, podendo ocupar lugares distintos na inflorescência; perianto ausente ou modificado em um hipogínio geralmente trilobado, inteiro, fimbriado ou ciliado; flores masculinas com 1-3 estames, femininas com 3 estigmas, algumas vezes plumosos, estiletes curtos, glabros, estilopódio ausente. Aquênios globosos, ovóides a trígonos, brancos ou purpúreos, lisos, reticulados ou verrucosos.

Chave para as espécies de Scleria

1. Planta escandente 5. S. secans

1. Planta ereta

2. Hipogínio nulo

3. Aquênios com superfície lisa, glumas esverdeadas, pilosas na região mediana .

1. S. hirtella

3. Aquênios com superfície geralmente verrucosa, glumas pardo-purpúreas, glabras

2. S. interrupta

2. Hipogínio trilobado

4. Hipogínio fimbriado, aquênio glabro ......

3. S. latifolia

4. Hipogínio inteiro, aquênio esparsamente piloso

4. S. melaleuca
13.1. Scleria hirtella Sw., Prodr. 1: 19. 1788.

Fig. 152-156

Perenes, cespitosas. Caules 25-35(40)x(0,05) $0,1-0,15 \mathrm{~cm}$, triquetros, eretos ou levemente pendentes, lisos, glabros. Folhas menores que o caule, geralmente não alcançando a base da inflorescência, ca. $2 \mathrm{~mm}$ larg., basais ou ao longo do escapo, lineares, glabras; bainhas purpúreas a pardas, pilosas nos bordos e na região mediana; contralígula levemente deltóide, ciliada. Inflorescências espiciformes com 3-6 glomérulos laterais, brácteas ca. $5 \mathrm{~mm}$, obovadas, mucronadas, pilosas na região mediana abaxial; espiguetas 3$5 \mathrm{xca} .1 \mathrm{~mm}$, ovadas a oblongas; glumas $2-3 \mathrm{~mm}$, helicoidais, obovadas, mucronadas, pilosas ao longo da nervura central, esverdeadas; hipogínio ausente; estame 1; estigmas 3 , estilete glabro. Aquênios ca. $1 \mathrm{~mm}$ diâm., globosos, com base trígona, brancos, superfície lisa.

Material examinado: BRASIL. Espírito Santo: Formação Brejo Herbáceo, I/1996 (fl., fr.), Martins 674 (VIC, UFP).

S. hirtella caracteriza-se pela inflorescência espiciforme com espiguetas dispostas em 3-6 glomérulos laterais, pelas glumas esverdeadas, pilosas na região mediana e aquênio liso. Ocorre somente na formação Brejo Herbáceo, e ainda assim é pouco abundante. Muniz \& Shepherd (1987) citam esta espécie como ocorrente em bordos de brejos e campos úmidos, ambientes semelhantes à formação Brejo Herbáceo mas pouco similares à formação Pós-praia. Segundo Core (1952) S. hirtella ocorre no Amazonas, Bahia, Minas Gerais, São Paulo, Paraná, Santa Catarina, Rio Grande do Sul, Ceará e Amapá e sua distribuição abrange as Américas, dos Estados Unidos ao Chile, e a África.

13.2. Scleria interrupta Rich., Act. Soc. Hist. Nat. Paris 1: 113. 1792.

Fig. 157-161

Anuais, cespitosas. Caules 20-40(45)cm, triquetros, sulcados, eretos ou levemente pendentes, glabros. Folhas menores que o caule, geralmente não alcançando a base da espiga, ca. $2 \mathrm{~mm}$ larg., basais ou caulinares, lineares, glabras; 
bainhas pardo-purpúreas, esparsamente pilosas; contralígula obtusa a deltóide, com bordo membranáceo. Inflorescências espiciformes com 3-6 glomérulos laterais, brácteas ca. $4 \mathrm{~mm}$, obovadas, mucronadas, esparsamente pilosas na região basal, espiguetas $3-4 x c a .1 \mathrm{~mm}$, ovadas a oblongas; glumas ca. $3 \mathrm{~mm}$, helicoidais, obovadas, mucronadas, glabras, pardo-purpúreas; hipogínio ausente, estame 1, estigmas 3. Aquênios ca. de $1 \mathrm{~mm}$ diâm., globosos, com base trígona, superfície verrucosa ou mais raramente lisa.

Material examinado: BRASIL, Espírito Santo: Formação Pós-praia, III/1996 (fl., fr.), Martins 727 (VIC, UFP).

$S$. interrupta caracteriza-se pela inflorescência espiciforme com espiguetas dispostas em 3-6 glomérulos laterais, e diferencia-se de $S$. hirtella por apresentar glumas pardo-purpúreas, glabras e aquênio geralmente com superfície verrucosa. Encontrada apenas na Formação Póspraia. Segundo Core (1952), essa espécie ocorre no Ceará e Pernambuco e sua distribuição abrange as Antilhas, a América Central e norte da América do Sul.

13.3. Scleria latifolia Sw., Prodr. 1: 18. 1788. Fig. 162-167

Perenes, cespitosas. Rizomas curtos, ca. $0,7 \mathrm{~cm}$ diâm. Caules $80-120 x(0,15) 0,4-0,6(0,8) \mathrm{cm}$, triquetros, esverdeados ou pardo-purpúreos, eretos, antrorsamente escabrosos, geralmente pilosos, pêlos curtos e esparsos. Folhas 21-53×2$4 \mathrm{~cm}$, predominantemente basais, oblongolanceoladas, assimétricas, acuminadas, antrorsamente escabrosas, pilosas; bainhas aladas, retrorsamente escabrosas; contralígula deltóide. Inflorescências terminais (1) e axilares (1), paniculiformes, cônicas ou piramidais, até $10 \mathrm{~cm}$ compr., com os raios verdes a fortemente purpúreos; espiguetas 3-4xca. $1 \mathrm{~mm}$, oval-lanceoladas; glumas das espiguetas femininas ca. $3 \times 3 \mathrm{~mm}$, ovadas, mucronadas, glumas das espiguetas masculinas ca. $3 \times 1-2 \mathrm{~mm}$, lanceoladas, mucronadas; as femininas 1-2, sésseis, as masculinas 14, pediceladas, acompanhadas por uma bractéola filiforme; hipogínio trilobado, com bordos fimbriados, purpúreos; estames 3; estigmas 3.
Aquênios 3-4×3mm, globosos, negros ou purpúreos, algumas vezes com a base branca, superfície lisa.

Material examinado: BRASIL. Espírito Santo: Lagoa Feia, V/1996 (fl., fr.), Martins 731 (VIC); Lagoa Vermelha, VI/1996 (fl., fr.), Martins 748 (VIC); Mata Periodicamente Inundada, VIII/ 1996 (fl., fr.), Martins 796 (VIC).

S. latifolia caracteriza-se por apresentar folhas assimétricas na extremidade, com bainhas largamente aladas e hipogínio trilobado, fimbriado, de coloração purpúrea a negra. Core (1936; 1952) diferencia $S$. latifolia de $S$. arundinaceae Kunth pela coloração da inflorescência, que nesta última seria púrpuro-escura e na primeira, marrom ou parda. O próprio autor sugere que $S$. arundinaceae seja uma variação de $S$. latifolia. Adams citado por Davidse et al. (1994) considera ambas as espécies como sinônimos, prevalecendo o nome S. latifolia por ser o mais antigo. Provavelmente, a coloração da inflorescência é caráter altamente variável, podendo sofrer alterações inclusive de acordo com habitat da espécie, principalmente com relação à exposição aos raios solares; desta forma preferiu-se considerar $S$. arundinaceae como variação de $S$. latifolia. Foi encontrada na Mata Periodicamente Inundada e nos bordos das lagoas Feia e Vermelha, onde a vegetação é arbórea. De acordo com Muniz \& Shepherd (1987), esta espécie é comum em matas, principalmente na mata atlântica. No Brasil ocorre no Rio de Janeiro, Santa Catarina, Rio Grande do Sul, São Paulo, Paraná, Minas Gerais, Pará (Core 1952), Bahia e Maranhão (Core 1936); distribuise desde a América Central à Argentina e Paraguai (Core 1952).

13.4. Scleria melaleuca Rchb. ex Schlecht. \& Cham., Linnaea 6: 29. 1831.

Fig. 168-171

Perenes, cespitosas. Rizomas ca. $3 \mathrm{~mm}$, nodosos. Caules $45-65 \times(0,15) 0,3-0,4 \mathrm{~cm}$, triquetros, eretos, glabros. Folhas $20-30(32) \times 0,3-0,7 \mathrm{~cm}$, predominantemente basais, lineares, retrorsamente escabrosas, pilosas; bainhas purpúreas, algumas vezes curtamente aladas; contralígula triangular, truncada, pilosa ou glabra. Inflorescências 3-6x1- 


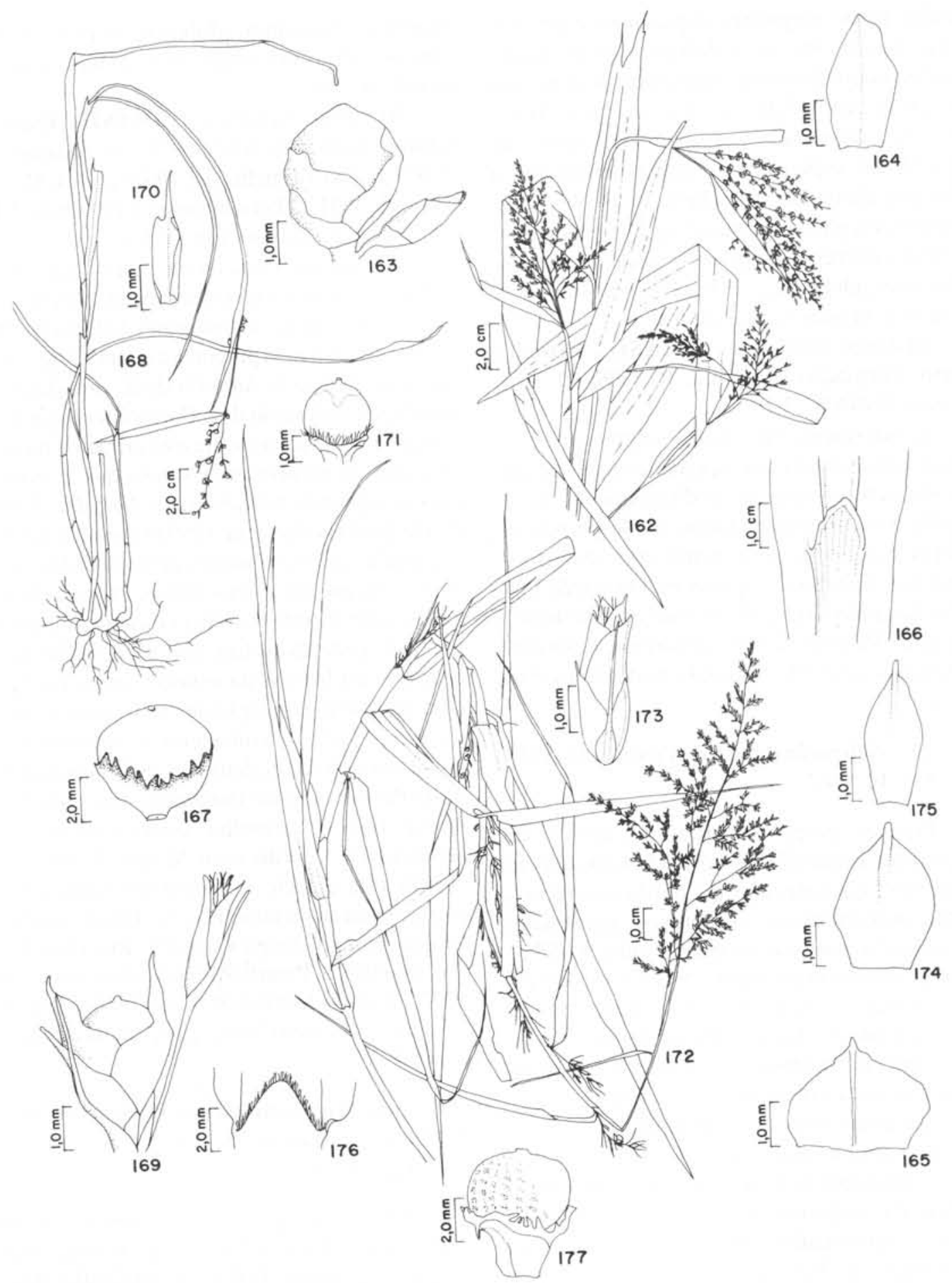

Figuras 162-177. Scleria latifolia Sw. 162. Aspecto geral; 163. Espigueta; 164. Gluma da flor masculina; 165. Gluma da flor feminina; 166. Porção distal da bainha; 167. Aquênio (Martins 796). Scleria melaleuca Rchb. ex Schlecht. \& Cham. 168. Aspecto geral; 169. Espigueta: 170. Gluma; 171. Aquênio (Martins 737). Scleria secans (L.) Urb. 172. Aspecto geral; 173. Espigueta; 174. Gluma da flor feminina; 175. Fluma da flor masculina; 176. Porção distal da bainha; 177. Aquênio (Martins 807). 
$2 \mathrm{~cm}$, terminais (1) e axilares (1), paniculiformes, pouco densas, purpúreas, acompanhadas por brácteas foliáceas; espiguetas ca. 3 xca. $1 \mathrm{~mm}$, as masculinas pediceladas, ovadas; as femininas sésseis ou subsésseis axilares; glumas das espiguetas femininas obovado-orbiculares, mucronadas, pardo-purpúreas, glabras, glumas das espiguetas masculinas oval-lanceoladas; flores díclinas; hipogínio trilobado, rígido, pardo com bordo claro; estame 1, estigmas 3, estilete glabro. Aquênios 2-2,5×2-2,5mm, globosos, apiculados, brancos na base, algumas vezes arroxeados no ápice, dispersamente pilosos, superfície lisa.

Material examinado: BRASIL. Espírito Santo: Formação Mata Seca, V/1996 (fl., fr.), Martins 737 (VIC).

$S$. melaleuca diferencia-se das demais espécies do gênero Scleria do PEPCV por apresentar um aquênio piloso em sua porção basal. Está restrita à formação Mata Seca onde ocorre tanto no bordo quanto no interior da mata. Adams citado por Davidse et al. (1994) cita-a para bordos de matas e campos e Core (1936) destaca sua preferência por ambientes úmidos. Ocorre no Amazonas, Pará, Rio de Janeiro, Minas Gerais, São Paulo (Core 1952), Paraíba e Pernambuco (Luceño et al. 1997). Sua distribuição é tropical e subtropical, nos continentes americano, do sul do México à Argentina, africano, na África tropical (Adams citado por Davidse et al. 1994).

13.5. Scleria secans (L.) Urb., Symb. Antill. 2: 169.1900.

Schoenus secans L., Syst. Nat. 10: 865. 1759. Fig. 172-177

Perenes, cespitosas. Rizomas curtos. Caules 7-8mx2-5mm, trígonos, escandentes, escabrosos, glabros. Folhas (16)20-26(28)x0,7-1,5cm, ao longo do caule, lineares, antrorsamente escabrosas, glabras; bainhas pilosas, verdes ou purpúreas; contralígula deltóide, marcadamente ciliada. Inflorescências terminais (1) e axilares (34), paniculiformes; espiguetas 3-4x1-2mm, masculinas, terminais, ovóides; espiguetas femininas axilares; glumas das espiguetas masculinas $2-4 \times 1-2 \mathrm{~mm}$, helicoidais, ovadas, púrpuro-amarronzadas, das femininas 5-6x3-4mm, triangulares, púrpuro-esverdeadas; hipogínio trilobado, reflexo; estames 2; estigmas 3 , estilete curto. Aquênios 3-4x3-4mm, globosos, brancos a arroxeados, superfície rugosa.

Material examinado: BRASIL. Espírito Santo: Formação Mata Seca, Martins 807 (fl., fr.), XII/1996 (VIC).

S. secans, conhecida popularmente como navalha-de-macaco, caracteriza-se por apresentar folhas e caules altamente cortantes e pelo hábito escandente. Ocorre nos bordos da formações Mata Seca, no entanto, Muniz \& Shepherd (1987) incluem-na como ocorrente apenas em interior de mata; há registros para a Bahia, Rio de Janeiro, Minas Gerais, Santa Catarina, Rio Grande do Sul (Core 1952), Paraíba e Pernambuco (Luceño et al. 1997). Distribui-se pelas Antilhas, e nas Américas, do México à Bolívia (Core 1936).

\section{Agradecimentos}

Aos professores Oberdan José Pereira e Alexandre Francisco da Silva, pela leitura crítica do manuscrito; à CAPES, pela concessão de bolsa ao primeiro Autor e aos Assessores pelas sugestões, que contribuiram para o aprimoramento do texto.

\section{Referências bibliográficas}

Araújo, D. S. D. \& Henriques, R. P. B. 1984. Análises florísticas das restingas do Estado do Rio de Janeiro Pp. 159-193. In: L. D. Lacerda; D. S. D. Araújo R. Cerqueira, \& B. Turck (Orgs.), Restingas: origem, estrutura, processos. CEUFF, Niterói.

Barros, M. 1960. Las Cyperaceae del Estado de Santa Catalina. Sellowia 2: 181 .

Berghen, C. V. 1988. Monocotylédones et Pteridophytes. Flore Ilustrée du Senegal 9: 137-347.

Core, E. L. 1952. The genus Scleria in Brazil. Rodriguésia 15: $137-162$.

Core, E. L. 1936. The American species of Scleria. Brittonia 2: $1-109$

Davidse, G.; Souza, M. \& Chater, A. O. 1994. Flora Mesoamericana. Alismataceae a Cyperaceae 6: $402-$ 500.

Fabris, L. C.; Pereira, O. J. \& Araújo, D. S. D. 1990. Análise fitossociológica na formação pós-praia da restinga de Setiba, Guarapari, ES. Pp. 3: 455-460. In: Simpósio de ecossistemas da costa sul e sudeste brasileira: estrutura, função e manejo. 1990, Águas de Lindóia, SP. Anais... Águas de Lindóia: ACIESP, SP. 
Guaglianone, E. R. 1979. Sobre Rhynchospora rugosa (Vahl) Gale (Cyperaceae) y algunas especies afines. Darwiniana 22: $255-311$.

Koyama, T. 1979. Cyperaceae. Pp. 3: 220-320. In: R. A. Howard (Ed.). Flora of the Lesser Antilles: Monocotyledoneae. Harvard University.

Koyama, T. 1970. The American species of the Hypolytrum. Darwiniana 16: 49-92.

Koyama, T. \& Maguire, B. 1965. Cyperaceae tribe Lagenocarpae. Memoirs of the New York Botanical Garden 12: 8-34.

Kral, R. A. 1971. Treatment of Abildgaardia, Bulbostylis and Fimbristylis (Cyperaceae) for North America. Sida 4: 57 227.

Luceño, M. \& Alves, M. V. 1997. Clave de los géneros de ciperáceas de Brasil y novedades taxonomicas y corológicas en la família. Candollea 52: 185-197.

Luceño, M.; Alves, M. V. \& Mendes, A. P. 1997. Catálogo florístico y claves de identificación de las ciperáceas de los estados de Paraíba e Pernambuco (Nordeste de Brasil). Anales del Jardín Botánico de Madrid 57: 67-100.

Muniz, C. 1987. Flora fanerogâmica da reserva do Parque Estadual das Fontes do Ipiranga (São Paulo, Brasil). Hoehnea 14: 95-102.

Muniz, C. \& Shepherd, G. J. 1987. O gênero Scleria Berg. (Cyperaceae) no Estado de São Paulo. Revista Brasileira de Botânica 10: 63-94.

Nees, C. G. 1842. Cyperaceae. Pp. 2(1): 1-226. In: Martius, C. F. P. Flora Brasiliensis, Monachii: Frid. Fleischer.

Pereira, O. J. 1990a. Caracterização fitofisionômica da restinga de Setiba -Guarapari - Espírito Santo. Pp. 3: 207 -
219. In: Simpósio de ecossistemas costeiros da costa sul e sudeste brasileira: estrutura, função e manejo. Águas de Lindóia, SP. Resumos... Águas de Lindóia: ACIESP, São Paulo.

Pereira, O. J. 1990b. Florística e fitossociologia de uma área de restinga do Estado do Espírito Santo. Dissertação de Mestrado. UFRJ, Rio de Janeiro.

Pereira, O. J. \& Gomes, J. M. L. 1993. Levantamento florístico das comunidades vegetais de restinga no município de Conceição da Barra, ES. Pp. 3: 67-78. In: Simpósio de ecossistemas costeiros da costa sul e sudeste brasileira: subsídios a um gerenciamento ambiental. Serra Negra, Resumos... Serra Negra: ACIESP, São Paulo.

Pereira, O. J.; Thomaz, L. D. \& Araújo, D. S. D. 1992. Florística e estrutura da vegetação de ante-dunas em praias de Guarapari e Vila Velha no Espírito Santo. Boletim do Museu de Biologia Mello Leitão (N. Ser.) 1: 65-75.

Scholz, H. \& Scholz, V. 1983. Flore descriptive des Cypéracées et Graminées du Togo. Phanerogamarum Monographiae 15: 5-119.

Svenson, H. 1929. Monographic studies in the genus Eleocharis-I. Rhodora 31: 119-243.

Svenson, H. 1937. Monographic studies in the genus Eleocharis-IV. Rhodora 39: 210-231.

Thomas, W. W. 1992. A synopsis of Rhynchospora (Cyperaceae) in Mesoamerica. Brittonia 44: 14-44.

Tucker, G. C. 1994. Revision of the Mexican species of Cyperus (Cyperaceae). Systematic Botany Monography 43: 1-213.

Uittien, H. 1966. Cyperaceae. Pp. 72-147. In: A. Pulle (Ed.), Flora of Suriname. E. J. Brill., Leiden (Reprint). 